University of Nebraska - Lincoln

DigitalCommons@University of Nebraska - Lincoln

U.S. National Park Service Publications and

Papers

National Park Service

9-3-2019

\title{
Permafrost Hydrology Drives the Assimilation of Old Carbon by Stream Food Webs in the Arctic
}

Jonathan A. O'Donnell

National Park Service, Arctic Network, jaodonnell@nps.gov

Michael P. Carey

U.S. Geological Survey

Joshua C. Koch

U.S. Geological Survey

Xiaomei Xu

University of California, Irvine

Brett A. Poulin

U.S. Geological Survey

Follow this and additional works at: https://digitalcommons.unl.edu/natlpark

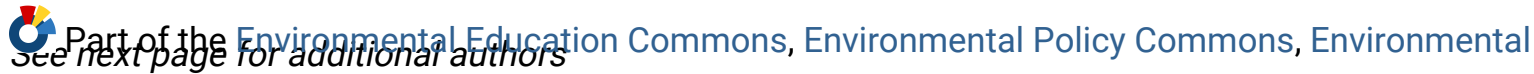
Studies Commons, Fire Science and Firefighting Commons, Leisure Studies Commons, Natural Resource Economics Commons, Natural Resources Management and Policy Commons, Nature and Society Relations Commons, Other Environmental Sciences Commons, Physical and Environmental Geography Commons, Public Administration Commons, and the Recreation, Parks and Tourism Administration Commons

O’Donnell, Jonathan A.; Carey, Michael P.; Koch, Joshua C.; Xu, Xiaomei; Poulin, Brett A.; Walker, Jennifer; and Zimmerman, Christian E., "Permafrost Hydrology Drives the Assimilation of Old Carbon by Stream Food Webs in the Arctic" (2019). U.S. National Park Service Publications and Papers. 205. https://digitalcommons.unl.edu/natlpark/205

This Article is brought to you for free and open access by the National Park Service at DigitalCommons@University of Nebraska - Lincoln. It has been accepted for inclusion in U.S. National Park Service Publications and Papers by an authorized administrator of DigitalCommons@University of Nebraska - Lincoln. 


\section{Authors}

Jonathan A. O'Donnell, Michael P. Carey, Joshua C. Koch, Xiaomei Xu, Brett A. Poulin, Jennifer Walker, and Christian E. Zimmerman 


\title{
Permafrost Hydrology Drives the Assimilation of Old Carbon by Stream Food Webs in the Arctic
}

\author{
Jonathan A. O’Donnell, ${ }^{1 *}$ ๑ Michael P. Carey, ${ }^{2}$ Joshua C. Koch, ${ }^{2}$ \\ Xiaomei Xu, ${ }^{3}$ Brett A. Poulin, ${ }^{4}$ Jennifer Walker, ${ }^{3,5}$ and \\ Christian E. Zimmerman ${ }^{2}$
}

\begin{abstract}
${ }^{1}$ National Park Service, Arctic Network, 240 W. 5th Avenue, Anchorage, Alaska 99501, USA; ${ }^{2}$ Alaska Science Center, U.S. Geological Survey, 4210 University Drive, Anchorage, Alaska 99508, USA; ${ }^{3}$ Keck Carbon Cycle AMS Facility, Department of Earth System Science, University of California, Irvine, California 92697, USA ${ }^{4}$ U.S. Geological Survey, 3215 Marine Street, STE E127, Boulder, Colorado 80303, USA; ${ }^{5}$ Present address: Andre E Lalonde AMS Laboratory, University of Ottawa, Ottawa, Ontario K1N 6N5, Canada
\end{abstract}

\begin{abstract}
Permafrost thaw in the Arctic is mobilizing old carbon (C) from soils to aquatic ecosystems and the atmosphere. Little is known, however, about the assimilation of old $\mathrm{C}$ by aquatic food webs in Arctic watersheds. Here, we used C isotopes $\left(\delta^{13} \mathrm{C}, \Delta{ }^{14} \mathrm{C}\right)$ to quantify $\mathrm{C}$ assimilation by biota across 12 streams in arctic Alaska. Streams spanned watersheds with varying permafrost hydrology, from ice-poor bedrock to ice-rich loess (that is, yedoma). We measured isotopic content of (1) C sources including dissolved organic C (DOC), dissolved inorganic C (DIC), and soil C, and (2) stream biota, including benthic biofilm and macroinvertebrates, and resident fish species (Arctic Grayling (Thymallus arcticus) and Dolly Varden (Salvelinus malma)). Findings document the assimilation of old C by stream biota, with depleted $\Delta{ }^{14} \mathrm{C}$ values observed at multiple trophic levels, including benthic biofilm $\left({ }^{14} \mathrm{C}\right.$ ages $=5255$ to
\end{abstract}

Received 20 February 2019; accepted 10 June 2019

Electronic supplementary material: The online version of this article (https://doi.org/10.1007/s10021-019-00413-6) contains supplementary material, which is available to authorized users.

JO-Designed study, performed research, analyzed data, wrote paper; MC/JK/CZ—Designed study, performed research; XX/BP/JW-Performed research.

*Corresponding author; e-mail: jaodonnell@nps.gov
265 years before present (y BP)), macroinvertebrates ( 4490 y BP to modern), and fish ( 3195 y BP to modern). Mixing model results indicate that DOC and DIC contribute to benthic biofilm composition, with relative contributions differing across streams draining ice-poor and ice-rich terrain. DOC originates primarily from old terrestrial $\mathrm{C}$ sources, including deep peat horizons $(39-47 \% ; 530$ y BP) and near-surface permafrost (12-19\%; 5490 y BP). DOC also accounts for approximately half of fish isotopic composition. Analyses suggest that as the contribution of old C to fish increases, fish growth and nutritional status decline. We anticipate increases in old DOC delivery to streams under projected warming, which may further alter food web function in Arctic watersheds.

Key words: Arctic; Dissolved organic matter; Streams; Permafrost; Food webs; Radiocarbon; Carbon cycle.

\section{HighLights}

- Stream biota can take up old carbon transported from permafrost soils. 
- Old carbon enters the food web through both organic and inorganic forms.

- As permafrost thaws, increasing delivery of old carbon could alter stream food web dynamics.

\section{INTRODUCTION}

Permafrost soils store large reservoirs of organic carbon $(\mathrm{C})$ that are mobilized upon thawing of the perennially frozen ground (Hugelius and others 2014). The release of permafrost $C$ to the atmosphere as greenhouse gases is of primary concern, given the potential for warming effects (Schuur and others 2015). Model estimates indicate that permafrost thaw may release 92 petagrams (Pg, or $10^{15}$ g) of C by 2100 , with the magnitude of warming dependent upon the fraction of $\mathrm{C}$ emitted as either carbon dioxide $\left(\mathrm{CO}_{2}\right)$ or methane $\left(\mathrm{CH}_{4}\right)$ (Schuur and others 2015). Permafrost thaw may also alter the lateral transfer of particulate and dissolved $\mathrm{C}$ forms (organic vs. inorganic) from terrestrial to aquatic ecosystems (Guo and others 2007; Frey and McClelland 2009; Aiken and others 2014; Tank and others 2016). In arctic rivers and lakes, terrestrial organic matter is the dominant source of dissolved organic carbon (DOC; for example, Wauthy and others 2018), originating from both contemporary (that is, post-1950s) and ancient C pools ( $>50,000$ years old). While evidence indicates that aquatic $\mathrm{C}$ fluxes are dominated by modern $\mathrm{C}$ (Aiken and others 2014; Elder and others 2018; Dean and others 2018), permafrost thaw will likely increase the release of old DOC from Holocene- and Pleistocene-aged deposits to surface waters and facilitate greater rock-water interaction and delivery of old dissolved inorganic C (DIC) from carbonate mineral weathering to streams (Frey and McClelland 2009). The fate of old $\mathrm{C}$ in aquatic ecosystems is uncertain, due to the complex interaction of physical, chemical, and biological controls on $\mathrm{C}$ turnover and transport. While prior research has quantified gaseous and dissolved $\mathrm{C}$ fluxes from arctic rivers and lakes, little is known about the uptake and assimilation of old $\mathrm{C}$ by aquatic food webs.

Old C may play a significant role in the composition and productivity of aquatic food webs (Bellamy and Bauer 2017; Guillemette and others 2017), particularly in watersheds draining permafrost landscapes (Schell 1983). Glacier melt and permafrost thaw release old organic C to aquatic ecosystems (Hood and others 2009; Aiken and others 2014). In both glacierand permafrost-dominated catchments, a large fraction of old DOC is highly bio-labile and thus susceptible to rapid mineralization and transformation by microbial communities (Hood and others 2009; Drake and others 2015; Mann and others 2015; Spencer and others 2015). Using radiocarbon $\left({ }^{14} \mathrm{C}\right)$ measurements of food web components, Fellman and others (2015) documented the assimilation of old organic C (dissolved and particulate) by stream macroinvertebrates and fish in glacial streams of southeast Alaska. Similarly, Schell (1983) reported the incorporation of old peat-derived $\mathrm{C}$ by resident fish and ducks in freshwater ecosystems of northern Alaska. Still, many uncertainties exist regarding the pathways of old C assimilation by stream food webs, particularly in areas underlain by warming permafrost. Old DIC originating from mineral weathering can also be incorporated into aquatic food webs (for example, Ishikawa and others 2014), creating a "reservoir effect" that must be accounted for when interpreting ages of stream biota (Guillemette and others 2017).

Permafrost exerts a strong control on subsurface hydrology in northern high-latitude watersheds (Walvoord and others 2012) and in turn governs the amount, form, and age of $\mathrm{C}$ delivered to aquatic ecosystems (Striegl and others 2005; Dornblaser and Striegl 2015; Tank and others 2016). The hydraulic properties of permafrost, as determined in part by soil texture, phase, and ground-ice content, influence subsurface water flow paths and consequently the chemistry of receiving waters (Barnes and others 2018; Dean and others 2016; Frey and McClelland 2009). For instance, streams draining catchments dominated by ice-rich silt tend to have higher concentrations of aromatic, young dissolved organic matter (DOM) than streams draining catchments underlain by ice-poor, coarse-grained soils ( $\mathrm{O}^{\prime}$ Donnell and others 2014, 2016). Silt-dominated soils also have lower hydraulic conductivity when frozen, enhancing lateral flow to surface waters (Koch and others 2013) and elevated DOC concentrations in surface waters (O'Donnell and others 2014, 2016). DIC concentrations typically exceed DOC concentrations in streams draining coarse-grained or ice-poor catchments, reflecting deep groundwater discharge and delivery of carbonate mineral weathering products to streams (Dornblaser and Striegl 2015; Toohey and others 2016). Incorporation of dissolved $\mathrm{C}$ into aquatic food webs is primarily through benthic biofilm, by either DIC uptake by photosynthetic algae or DOC uptake and assimilation by aquatic heterotrophs (that is, benthic microbial communities; Battin and others 2016). The age of dissolved $\mathrm{C}$ assimilated by primary producers or consumers will likely influence the ${ }^{14} \mathrm{C}$ age of organisms at higher trophic levels, including macroinvertebrates and fish. 
Here, we examine the role of permafrost hydrology on the source, age, form, and assimilation of $C$ by stream food webs in headwater catchments of arctic Alaska. We sampled soil, water, and stream biota from watersheds that vary with subsurface hydraulic properties as determined by dominant parent material and ground-ice content ( $\mathrm{O}^{\prime}$ Donnell and others 2016). Using radiocarbon $\left({ }^{14} \mathrm{C}\right)$ and stable $C$ isotope measurements $\left({ }^{13} \mathrm{C}\right)$, we characterized the isotopic composition of food web components (benthic biofilm, benthic macroinvertebrates, and resident fish) and $\mathrm{C}$ sources (terrestrial peat, stream DOC and DIC; Figure 1). Using isotopic mixing models, we quantify the relative contribution of contemporary and old $\mathrm{C}$ sources (including permafrost C) to the stream DOC pool, benthic biofilm, and resident fish diet. We further explore how the potential for increased contributions of old $\mathrm{C}$ with permafrost thaw may alter growth and nutritional status of resident fish communities.

\section{Methods}

\section{Study Region}

We sampled 12 headwater streams draining watersheds spanning a gradient of permafrost characteristics based on soil parent material types and ground-ice content in the Bering Land Bridge and Noatak National Preserves (Figure 2). All data that support the findings of this publication can be found in Carey and others (2019).The Agashashok River, a tributary of the lower Noatak River, drains an ice-poor landscape ( $<10 \%$ by volume) and is underlain primarily by carbonate bedrock and poorly developed alkaline soils (O'Donnell and others 2016). The Cutler and Imelyak Rivers in the upper Noatak River drain a watershed underlain by glaciolacustrine deposits with moderate to high ground-ice content (O'Donnell and others 2016). The Pish River drains a watershed underlain by icerich Pleistocene loess (that is, yedoma) on the Seward Peninsula (Kanevskiy and others 2011). Prior work at these sites has shown the importance of permafrost characteristics as a control on the chemical composition of DOM in stream and river water (O'Donnell and others 2016). Vegetation in the study region is dominated by arctic tundra and boreal spruce (Picea mariana and P. glauca). Tall and low shrubs are common along river floodplains and hillslope drainage ways, and near tree line (Swanson 2015), and have generally expanded in abundance throughout the region in recent decades (Tape and others 2006).

\section{Stream Chemistry}

Water samples were collected during the openwater periods between June and September over 2 years (2015-2016). Samples were collected for

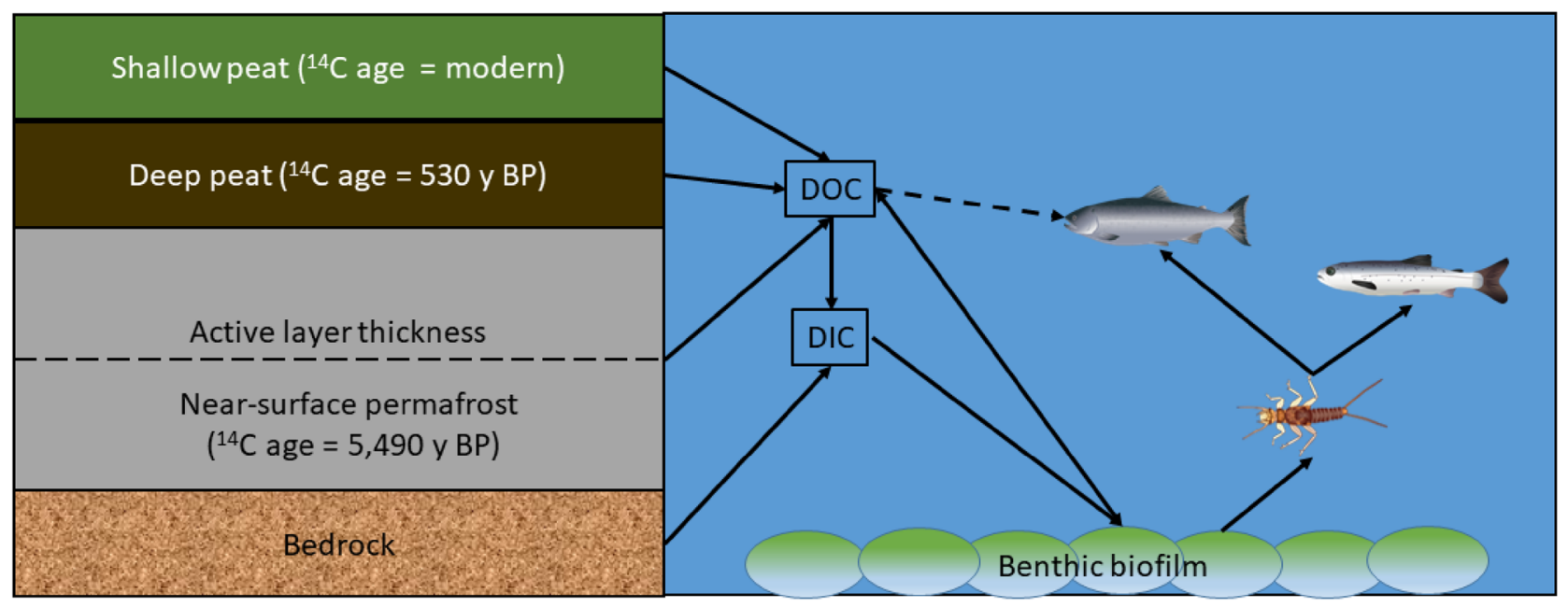

Figure 1. Conceptual diagram illustrating the hypothesized pathways of dissolved C transport from terrestrial to stream ecosystems, and subsequent incorporation into stream food webs. Terrestrial organic C sources were separated into contemporary shallow peat horizons, older deep peat horizons, and near-surface permafrost. Stream DOC is a mixture of these three allochthonous sources and one autochthonous source (benthic biofilm; Model 1). Stream DIC is derived from both mineral weathering inputs, mineralization of organic carbon, and through equilibration with $\mathrm{CO}_{2}$ in the atmosphere. Benthic biofilm isotopic composition is determined by DOC uptake by microbes and DIC uptake by algae (Model 2). Resident fish isotopic composition is likely a mixture of benthic macroinvertebrates, although we explore DOC as an additional end-member in Model 3. 


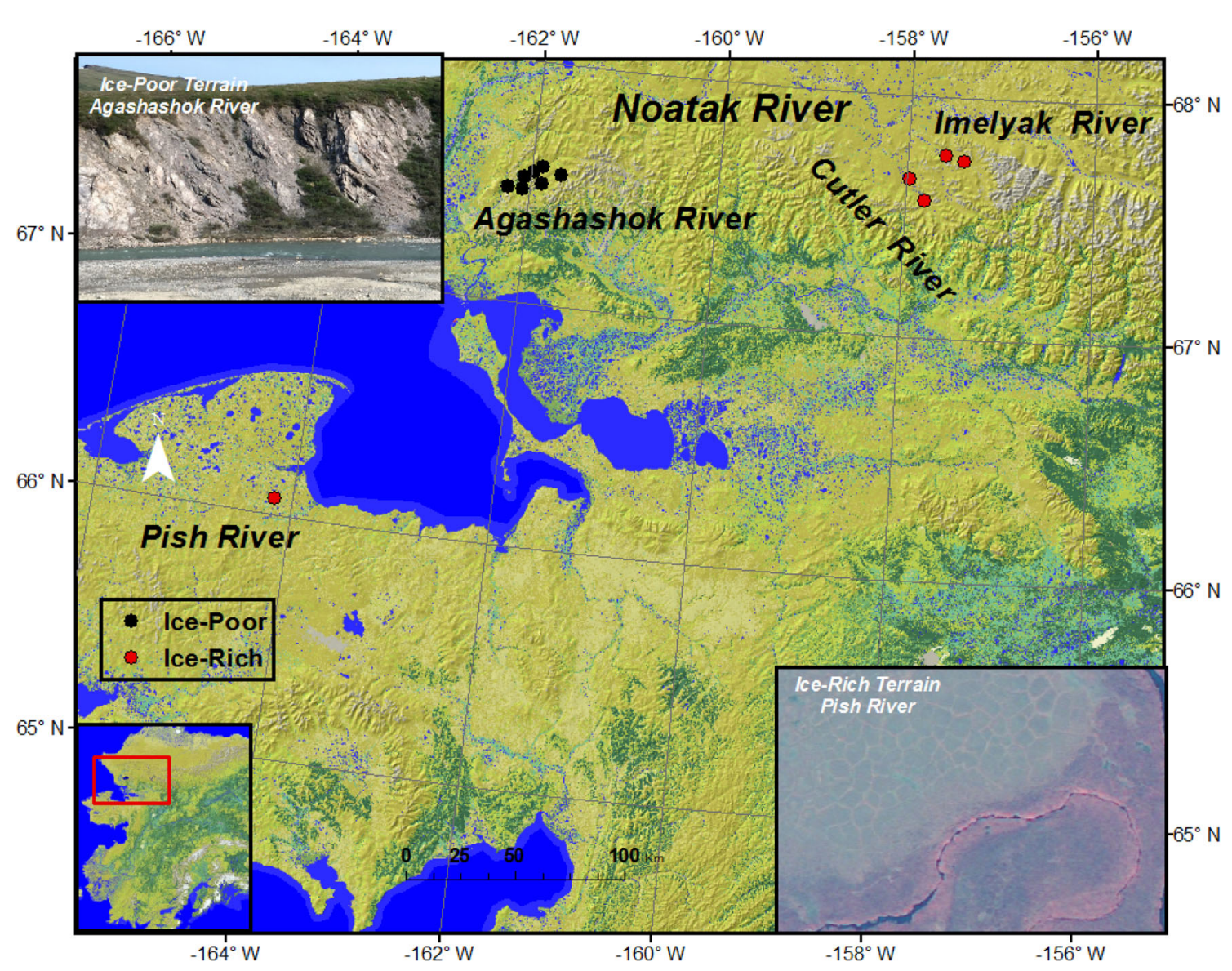

Figure 2. Map identifying the location of ice-rich (black symbols) and ice-poor (red symbols) study sites in northwest Alaska (highlighted by red box in upper right inset). Headwater streams of the Agashashok watershed are underlain by icepoor bedrock (upper-left picture). The Cutler and Imelyak watersheds are underlain by ice-rich glaciolacustrine deposits, and the Pish watershed is underlain by ice-rich loess (that is, yedoma; lower-right picture) (Color figure online).

measurement of DOC concentration and DOM optical properties using a $0.45-\mu \mathrm{m}$ high-capacity capsule filter connected to a Geopump Series II Peristaltic Pump (Geotech Environmental Equipment, Inc., Denver, CO). DOC concentrations were determined using an O.I. Analytical Model 700 TOC analyzer via the platinum catalyzed persulfate wet oxidation method (Aiken 1992). UV-visible absorbance was measured on filtered stream samples at room temperature using a quartz cell with a path length of $1 \mathrm{~cm}$ on an Agilent Model 8453 photodiode array spectrophotometer. Specific UV absorbance at $254 \mathrm{~nm}\left(\mathrm{SUVA}_{254}\right)$ was determined for all stream samples by dividing the decadal UVvisible absorbance coefficient at $\lambda=254 \mathrm{~nm}$ by DOC concentration. SUVA $254\left(\mathrm{~L} \mathrm{mgC}^{-1} \mathrm{~m}^{-1}\right)$, which is typically used as an index of DOC aromaticity, provides an average absorptivity at $\lambda=254 \mathrm{~nm}$ of the DOM (Weishaar and others 2003). Prior work in the Yukon River basin has shown that $\mathrm{SUVA}_{254}$ is closely linked to the fraction of groundwater contributing to stream flow during the open-water season (O'Donnell and others 2012) and DOC age (Aiken and others 2014).

To determine DIC concentrations, stream water samples were collected without head space in a 60$\mathrm{mL}$ syringe. Immediately prior to analysis, water samples were filtered using $0.45-\mu \mathrm{m}$ nylon syringe filters into $40-\mathrm{mL}$ borosilicate vials clean vials and capped by septum caps to minimize interaction with the atmosphere. DIC concentrations were determined by acidifying with phosphoric acid and measuring on a Shimadzu TOC-VCSH Combustion Analyzer. Specific conductivity $\left(\mu \mathrm{S} \mathrm{cm}^{-1}\right)$ was also measured in situ using a YSI Professional Plus multiparameter sonde (YSI (Yellow Springs Instruments) Incorporated, Yellow Springs, $\mathrm{OH}$ ).

\section{Isotope Sampling and Measurements}

We collected water samples to determine the isotopic composition $\left(\delta^{13} \mathrm{C}, \Delta^{14} \mathrm{C}\right)$ of $\mathrm{C}$ sources to stream food webs in August 2016, including DOC, 
DIC, and organic-soil horizons (that is, peat; Figure 1). For $\Delta^{14} \mathrm{C}$-DOC measurements, we filtered $375 \mathrm{~mL}$ of stream water using a pre-rinsed $0.45-\mu \mathrm{m}$ high-capacity capsule filter in three replicate 125 mL square Nalgene polypropylene bottles in the field, and froze samples prior to processing. For $\Delta{ }^{14} \mathrm{C}$-DIC measurements, we collected unfiltered stream water in 1 L Pyrex glass bottles and preserved with $100 \mu \mathrm{L}$ of saturated $\mathrm{HgCl}_{2}$ solution. Organic-soil horizons were sampled from a nearby tundra site within the Cutler River basin to characterize the $\Delta^{14} \mathrm{C}$ and $\delta^{13} \mathrm{C}$ signatures of peat as a possible organic matter source to stream food webs. To sample soil, we dug a soil pit and described soil horizons following USDA-NRCS (Staff 1998) and Canadian (Soil Classification Working Group 1998) methods. Organic-soil horizons were then sampled by horizon type across the soil profile using a combination of knives and scissors. For mixing model analyses, we divided organic horizons into "Shallow Peat" (live and dead moss $=0-4 \mathrm{~cm}$, mesic horizon $=4-7 \mathrm{~cm}$ ) and "Deep Peat" (humic horizons $=10-25 \mathrm{~cm}$ ).

To characterize the isotopic signatures of stream food webs, we sampled benthic biofilms, aquatic macroinvertebrates, and resident fish species (Figure 1). Benthic biofilm was collected by scraping fully submerged rocks with visible organic material in all tributaries (following Fellman and others 2015). Biofilm samples were frozen for transport back to the laboratory. In the laboratory, biofilm samples were rinsed with deionized water to remove fine gravel and freeze-dried for $48 \mathrm{~h}$. Aquatic macroinvertebrates were sampled using a kick-net ( $n=8$ sites per tributary) in all tributaries and samples were then frozen for transport back to the laboratory. In the laboratory, macroinvertebrate samples were thawed and identified to family (Merritt and others 2008). To assist in macroinvertebrate identification, additional samples were collected at each tributary and processed by the BLM/USU National Aquatic Monitoring Center (The BugLab; www.usu.edu/buglab/). We submitted samples for isotope analysis from the family Nemouridae in the order Plecoptera (Stoneflies) and Chironomidae, as both families are generalists functioning as shredder-detritivores and facultative collectors (Merritt and others 2008). Nemouridae and Chironomidae from each location were freezedried for $48 \mathrm{~h}$ and submitted for $\delta^{13} \mathrm{C}$ and $\Delta^{14} \mathrm{C}$ analysis. Fish were collected in all tributaries using minnow traps and backpack electrofishing (Reynolds and Kolz 2013). All fish were identified to species and measured for fork length (to the nearest $\mathrm{mm}$ ) in the field. Dolly Varden (Salvelinus malma) and Arctic Grayling (Thymallus arcticus) were killed and frozen for transport back to the laboratory. In the laboratory, dorsal muscle tissue from Dolly Varden and Arctic Grayling (age 1-2 years) was dissected and freeze-dried for $48 \mathrm{~h}$ before being submitted for $\delta^{13} \mathrm{C}, \Delta \Delta^{14} \mathrm{C}$, and energy density measurements. A semimicro Parr 1425 calorimeter was used to measure energy density following the Parr manual (Parr Instrument Company 1994). Energy density, which we use as a proxy for nutritional status, from the calorimeter (cal g ${ }^{-1}$ dry mass) was converted to $\mathrm{mJ}$ and reported per unit mass ( $\mathrm{mJ} \mathrm{kg}^{-1}$ mass). Benzoic acid standard and duplicate tissue samples were used to evaluate the precision of the calorimeter.

$\Delta^{14} \mathrm{C}$ and $\delta^{13} \mathrm{C}$ of DOC in arctic stream samples were determined at the National Ocean Sciences Acceleratory Mass Spectrometry laboratory at the Woods Hole Oceanographic Institute (http://www. whoi.edu/nosams/home). For $\Delta^{14} \mathrm{C}$, DOC samples were diluted with ultra-low-carbon, 18.2 $\mathrm{M} \Omega$ Milli-Q water, acidified with $85 \%$ phosphoric acid, purged with ultra-high purity helium gas, and oxidized to $\mathrm{CO}_{2}$ using UV light for $4 \mathrm{~h}$ (Beaupre and others 2007). $\delta^{13} \mathrm{C}$ of DOC was determined using an Optima stable isotope ratio mass spectrometer. All other ${ }^{14} \mathrm{C}$ samples were analyzed at the W. M. Keck C Cycle AMS Laboratory at the University of California Irvine for analysis (Beverly and others 2010). For $\Delta^{14}$ C-DIC, samples were prepared for graphitization using the head-space extraction technique (Gao and others 2014). $\delta^{13} \mathrm{C}$ of DIC was determined using a Gas Bench coupled with an isotope ratio mass spectrometer (IRMS, Finnigan Delta Plus XL, Thermo Fisher Scientific, Pittsburgh, PA, USA), with a method similar to Torres and others (2005). Organic solid-phase samples (organic-soil horizons, biofilm, benthic macroinvertebrates, fish) were combusted at $900^{\circ} \mathrm{C}$ in evacuated, sealed quartz tubes in the presence of $\mathrm{CuO}$. Following cryogenic purification, $\mathrm{CO}_{2}$ was reduced to graphite at $550^{\circ} \mathrm{C}$ using the sealed tube $\mathrm{Zn}$ reduction method (Xu and others 2007). $\delta^{13} \mathrm{C}$ of organic-soil horizons and macroinvertebrates were determined in the Keck AMS laboratory using Gas Bench coupled with a Finnigan Delta Plus XL IRMS. $\delta^{13} \mathrm{C}$ of biofilm, macroinvertebrates, and fish species was determined on a Carlo Erba and Costech 4010 Elemental Analyzer coupled to a Thermo Delta Plus XP IRMS at the University of Wyoming Stable Isotope Facility (www.uwyo.edu/sif/). Radiocarbon data are reported as fraction modern (fM), radiocarbon age, and as $\Delta^{14} \mathrm{C}$, or the per mil deviation of the ${ }^{14} \mathrm{C} /{ }^{12} \mathrm{C}$ ratio in the sample from that of the oxalic acid standard (OX-I) decay-cor- 
rected to 1950 (Stuiver and Polach 1977). All ${ }^{14} \mathrm{C}$ values reported are corrected for mass-dependent fractionation using the AMS online $\delta^{13} \mathrm{C}$ measurements. One-way analysis of variance (ANOVA) was used to test for statistical differences in $\Delta^{14} \mathrm{C}$ values for $\mathrm{C}$ sources and food web components.

\section{Isotopic Mixing Analyses}

We used three individual two-isotope $\left(\delta^{13} \mathrm{C}, \Delta{ }^{14} \mathrm{C}\right)$ mixing analyses to assess linkages among permafrost hydrology (that is, ice-poor vs. ice-rich) and C source contribution to the DOC pool (Model 1 ), and C sources and assimilation in biofilm (Model 2) and resident fish species (Model 3). All mixing analyses were conducted within a Bayesian modeling framework (MixSIAR; Stock and Semmens 2013) in $\mathrm{R}$ (Team 2014). Bayesian mixing models improve upon classic linear mixing models by accounting for uncertainty associated with multiple source contributions to a mixture (Moore and Semmens 2008). Below, we detail three mixing models used to track flows of $\mathrm{C}$ of different sources and ages to the stream food web. In all three models, permafrost type (ice-poor vs. ice-rich) was prescribed as a fixed effect, and site ID was treated as a random effect within MixSIAR.

First, we used a four-end-member mixing model to determine organic $\mathrm{C}$ source contributions to the stream DOC pool across watersheds underlain by ice-rich and ice-poor permafrost (Model 1). We defined three allochthonous end-members (see Table 2): a contemporary organic $C$ source reflecting lateral inputs from shallow organic-soil horizons of the active layer (hereafter referred to as the shallow peat end-member), and one older $\mathrm{C}$ source reflecting inputs from deep organic-soil horizons (hereafter referred to as the deep peat end-member, $\sim 530 \pm 190$ y BP) and one near-surface permafrost end-member which may come from thawing permafrost (referred to permafrost endmember, 5490 y BP; Figure 1). The permafrost end-member $\left(\Delta^{14} \mathrm{C}=-498.3 \pm 216.0 \% ; \quad \delta^{13} \mathrm{C}=\right.$ $-26.3 \pm 1.3 \%$ o was defined based on isotope values from near-surface permafrost $(<1 \mathrm{~m}$ deep) on north-facing hillslopes in interior Alaska (O'Donnell and others 2011, 2013). We also defined an autochthonous $\mathrm{C}$ end-member, reflecting the $\mathrm{C}$ isotopic composition of the benthic biofilm. The biofilm end-member was defined by the $\mathrm{C}$ isotopic composition of benthic biofilm samples, which varied between streams draining ice-poor terrain $\left(\Delta^{14} \mathrm{C}=-380.6 \pm 90.1 \% ; \delta^{13} \mathrm{C}=-29.0 \pm\right.$ $3.4 \%, \quad N=7)$ and ice-rich terrain $\left(\Delta^{14} \mathrm{C}=\right.$ $\left.-118.2 \pm 83.4 \% ; \quad \delta^{13} \mathrm{C}=-36.8 \pm 4.9 \%, \quad N=5\right)$ (Table 2).

Second, we used a two-end-member mixing model to partition the uptake of DOC and DIC by benthic biofilm (Model 2), following methods of Small and others (2011) and Fellman and others (2015). The uptake and assimilation of ${ }^{14} \mathrm{C}$-depleted $\mathrm{C}$ by benthic biofilm can occur through two pathways: (1) fixation by benthic algae of old DIC derived from carbonate weathering, or (2) assimilation by aquatic heterotrophs of old DOC derived from deep soil C stocks. The DOC end-member was defined as the average isotope composition of DOC in streams draining ice-rich terrain $\left(\Delta^{14} \mathrm{C}=\right.$ $-47.6 \pm 38.5 \% ; \delta^{13} \mathrm{C}=-27.8 \pm 0.5 \%$ ) and icepoor terrain $\left(\Delta^{14} \mathrm{C}=-112.4 \pm 83.4 \% ; \quad \delta^{13} \mathrm{C}=\right.$ $-26.5 \pm 1.9 \%$; Table 2$)$. Similarly, the DIC endmember was defined as the average isotope composition of DIC in streams draining ice-rich terrain $\left(\Delta^{14} \mathrm{C}=-101.3 \pm 76.1 \% ; \quad \delta^{13} \mathrm{C}=-7.0 \pm 0.5 \%\right.$ \% and ice-poor terrain $\left(\Delta^{14} \mathrm{C}=-382.3 \pm 91.8 \%\right.$; $\delta^{13} \mathrm{C}=-6.1 \pm 2.1 \%$ ). We used a concentrationdependent weighting factor for the mixing analysis to account for differences in source concentrations of stream dissolved C (Phillips and Koch 2002). To account for differences among sources in the model, we used observed stream DOC and DIC concentrations (Table 1). We corrected stable isotope values of DIC sources by calculating a fractionation factor $(\epsilon)$, following Finlay (2004):

$$
\varepsilon(\%)=\frac{\delta 13 C_{\text {DIC }}-\delta 13 C_{\text {biofilm }}}{1+\delta 13 C_{\text {biofilm }} / 1000}
$$

where $\delta^{13} C_{D I C}$ is the $\delta^{13} \mathrm{C}$ value of DIC and $\delta^{13} \mathrm{C}_{\text {biofilm }}$ is the $\delta^{13} \mathrm{C}$ value of benthic biofilm for a given stream. Calculated fractionation factors averaged $26.6 \pm 2.2 \% \quad(n=12$ streams $)$ across streams draining ice-poor and ice-rich terrain.

Third, we conducted a two-end-member mixing analysis to examine the contribution of different pathways of C (DOC, benthic macroinvertebrates) to resident fish species (Arctic Grayling and Dolly Varden; Model 3; Table 2). For the DOC end-member, we used the same isotopic values as for the biofilm mixing model. For the benthic macroinvertebrate end-member, we calculated the average isotope values of both families together for ice-rich and for ice-poor sites, since we did not observe significant differences in $\mathrm{C}$ isotopic composition between chironomids and stoneflies within streams draining each permafrost types (Table 2). 
Table 1. Study Site Locations and Chemical Characteristics for all Study Sites

\begin{tabular}{|c|c|c|c|c|c|c|}
\hline $\begin{array}{l}\text { Site types, watersheds, } \\
\text { stream IDs }\end{array}$ & $\begin{array}{l}\text { Latitude } \\
\left({ }^{\circ} \mathrm{N}\right)\end{array}$ & $\begin{array}{l}\text { Longitude } \\
\left({ }^{\circ} \mathrm{W}\right)\end{array}$ & $\mathrm{pH}$ & $\begin{array}{l}\text { Specific conductivity } \\
\left(\mu \mathrm{S} \mathrm{cm}^{-1}\right)\end{array}$ & $\begin{array}{l}\text { DOC } \\
\left(\mathrm{mgC} \mathrm{L}^{-1}\right)\end{array}$ & $\begin{array}{l}\text { DIC } \\
\left(\mathrm{mgC} \mathrm{L}^{-1}\right)\end{array}$ \\
\hline \multicolumn{7}{|l|}{ Ice-poor bedrock sites } \\
\hline \multicolumn{7}{|c|}{ Agashashok River, North Fork } \\
\hline Tributary 2 & 67.569 & -161.886 & $8.1 \pm 0.1(8)$ & $489 \pm 45$ & $2.9 \pm 0.4(8)$ & $47.4 \pm 5.3(5)$ \\
\hline Tributary 3 & 67.545 & -161.963 & $8.1 \pm 0.1(8)$ & $695 \pm 57(7)$ & $2.9 \pm 0.5(7)$ & $46.5 \pm 4.7(4)$ \\
\hline Tributary 4 & 67.522 & -162.060 & $8.1 \pm 0.1(8)$ & $431 \pm 26(7)$ & $1.8 \pm 0.2(8)$ & $37.6 \pm 3.8(5)$ \\
\hline \multicolumn{7}{|c|}{ Agashashok River, South Fork } \\
\hline Tributary 1 & 67.545 & -161.681 & $8.1 \pm 0.1(8)$ & $431 \pm 52(7)$ & $0.7 \pm 0.0(8)$ & $32.7 \pm 3.7(4)$ \\
\hline Tributary 2 & 67.498 & -161.871 & $8.1 \pm 0.1(8)$ & $459 \pm 57(7)$ & $1.6 \pm 0.2(8)$ & $35.5 \pm 4.3(5)$ \\
\hline Tributary 4 & 67.472 & -162.071 & $8.1 \pm 0.1(8)$ & $414 \pm 34(7)$ & $3.8 \pm 0.3(8)$ & $40.6 \pm 4.8$ \\
\hline \multicolumn{7}{|c|}{ Agashashok River, Mainstem } \\
\hline Asik Creek & 67.475 & -162.234 & $7.8 \pm 0.1(8)$ & $305 \pm 22(6)$ & $1.2 \pm 0.1(8)$ & $30.8 \pm 2.9$ \\
\hline \multicolumn{7}{|l|}{ Ice-rich sites } \\
\hline \multicolumn{7}{|l|}{ Cutler River } \\
\hline Tributary 1 & 67.568 & -157.796 & $7.8 \pm 0.1$ & $290 \pm 76$ & $6.5 \pm 0.7(3)$ & $23.3 \pm 8.5$ \\
\hline Tributary 2 & 67.655 & -157.968 & $7.9 \pm 0.1$ & $261 \pm 10$ & $4.9 \pm 1.0(3)$ & $39.7 \pm 4.7(2)$ \\
\hline \multicolumn{7}{|l|}{ Imelyak River } \\
\hline Tributary 1 & 67.739 & -157.395 & $8.0 \pm 0.1$ & $321 \pm 19$ & $3.5 \pm 0.7(3)$ & $40.6 \pm 4.3$ \\
\hline Tributary 2 & 67.758 & -157.595 & $7.8 \pm 0.2$ & $330 \pm 5$ & $4.7 \pm 0.9(3)$ & $36.6 \pm 4.4$ \\
\hline \multicolumn{7}{|l|}{ Pish River } \\
\hline Tributary 2 & 66.068 & -164.179 & $6.9 \pm 0.6(2)$ & $87(1)$ & $23.5 \pm 0.1$ & $4.2 \pm 0.7(2)$ \\
\hline
\end{tabular}

Chemistry values reflect mean \pm one standard error (number of sample in parentheses) for all measurements during the summer-autumn open-water season (June through September) between 2015 and 2017.

\section{RESUltS}

\section{Patterns in Dissolved C Concentration and Isotopic Composition}

We observed differences in the concentration, form (organic vs. inorganic), and age of dissolved C across headwater streams draining ice-rich and icepoor terrain. On average, DOC concentration during the sampling period (August 2016) was generally lower in streams draining ice-poor terrain (average \pm one standard error $=2.1 \pm 0.2 \mathrm{mgC} \mathrm{L}^{-1}$, $n=55$; Table 1) compared to streams draining icerich terrain $\left(7.6 \pm 1.8 \mathrm{mgC} \mathrm{L}^{-1}, n=14\right)$. DIC concentration, by contrast, was higher in streams draining ice-poor terrain $\left(38.7 \pm 1.8 \mathrm{mgC} \mathrm{L}^{-1}\right.$, $n=33$; Table 1) than ice-rich terrain $(29.8 \pm 4.2$ $\left.\operatorname{mgC~} \mathrm{L}^{-1}, n=13\right)$. At both ice-rich and ice-poor sites, $\delta^{13} \mathrm{C}$-DOC values closely tracked the signature of $\mathrm{C} 3$ plants (range $=-28$ to $-26 \%$; Peterson and Fry 1987) and $\delta^{13} \mathrm{C}$-DIC values reflected either atmospheric or weathering sources from groundwater (range $=-9$ to $-3 \%$; Kendall and others 1992). However, we did observe significant differences in the $\Delta^{14} \mathrm{C}$ values and age of DIC (one-way ANOVA: $d f=1, F=26.6, P<0.001)$ across stream types (Figure 3A, Supplemental Table 1). $\Delta^{14} \mathrm{C}$ values for DOC were not statistically significant between ice-poor and ice-rich sites $(P=0.18)$. For ice-poor sites, $\Delta^{14} \mathrm{C}$-DOC averaged $-112.4 \pm$ $83.4 \%$ o $\left({ }^{14} \mathrm{C}\right.$ age range $=3430$ to 285 y before present (BP)) and $\Delta^{14} \mathrm{C}$-DIC averaged $-382.3 \pm$ $91.8 \%$ o $\left({ }^{14} \mathrm{C}\right.$ age range $=5030$ to 1660 y $\left.\mathrm{BP}\right)$. For ice-rich sites, $\Delta^{14} \mathrm{C}$-DOC averaged $-47.6 \pm 38.5 \%$ $\left({ }^{14} \mathrm{C}\right.$ age range $=790$ y $\mathrm{BP}$ to modern $)$ and $\Delta{ }^{14} \mathrm{C}$-DIC averaged $-101.3 \pm 76.1 \% \quad\left({ }^{14} \mathrm{C}\right.$ age range $=1550$ y $\mathrm{BP}$ to modern).

\section{Hydrological Controls on Dissolved C Age}

The age of dissolved $\mathrm{C}$ could be explained by the relative contribution of groundwater to stream discharge, as determined by optical proxies. $\Delta^{14} \mathrm{C}$ DOC is positively and nonlinearly correlated with SUVA $_{254}$ (Figure 4A). In general, SUVA 254 values, which are a proxy for DOM aromaticity, were higher in ice-rich sites than in ice-poor sites, which reflect differences in permafrost characteristics across watersheds and resulting subsurface hydrology delivering DOC to streams. In watersheds where stream discharge is primarily from near-surface runoff through supra-permafrost aquifers (for example, the active layer), $\mathrm{SUVA}_{254}$ values are relatively high $\left(>3.4 \mathrm{~L} \mathrm{mgC}^{-1} \mathrm{~m}^{-1}\right.$; O'Donnell and others 2012, 2016). Conversely, in 
Table 2. Summary of Mixing Model End-Member Values and Their Uncertainties for the Isotopic Mixing Analyses and Source of the Data

\begin{tabular}{|c|c|c|c|c|}
\hline End-member & $\delta^{13} \mathrm{C}(\%)$ & $\Delta^{14} \mathrm{C}(\%)$ & $\begin{array}{l}{ }^{14} \mathrm{C} \text { age }(\mathrm{y} \\
\mathrm{BP})\end{array}$ & Data source \\
\hline \multicolumn{5}{|c|}{ Model 1: Organic C sources to stream DOC? } \\
\hline Shallow peat & $-27.2 \pm 1.3$ & $113.2 \pm 16.8$ & Modern & $\begin{array}{l}\text { This study: live/dead moss from Cutler River basin } \\
\qquad(n=2)\end{array}$ \\
\hline Deep peat & $-26.2 \pm 0.3$ & $-71.6 \pm 21.9$ & $530 \pm 190$ & $\begin{array}{l}\text { This study: humic organic matter from Cutler River } \\
\text { basin }(n=3)\end{array}$ \\
\hline Permafrost & $-26.3 \pm 1.3$ & $-498.3 \pm 60.8$ & $6021 \pm 858$ & $\begin{array}{l}\text { O'Donnell and others }(2011) \text { : near-surface per- } \\
\text { mafrost }(<1 \mathrm{~m} \text { deep) from north-facing hillslope } \\
\text { in interior Alaska }(n=4)\end{array}$ \\
\hline Biofilm, ice-poor & $-29.0 \pm 3.4$ & $-380.6 \pm 90.1$ & $3780 \pm 1170$ & This study: from ice-poor streams $(n=7)$ \\
\hline Biofilm, ice-rich & $-36.3 \pm 1.3$ & $-118.2 \pm 83.4$ & $950 \pm 760$ & This study: from ice-rich streams $(n=5)$ \\
\hline \multicolumn{5}{|c|}{ Model 2: $C$ sources assimilated by benthic biofilm } \\
\hline DOC, ice-poor & $-26.5 \pm 1.9$ & $-112.4 \pm 83.4$ & $890 \pm 760$ & This study: from ice-poor streams $(n=7)$ \\
\hline DOC, ice-rich & $-27.8 \pm 0.5$ & $-47.6 \pm 38.5$ & $330 \pm 330$ & This study: from ice-rich streams $(n=5)$ \\
\hline DIC, ice-poor & $-6.1 \pm 2.1$ & $-382.3 \pm 91.8$ & $3810 \pm 1200$ & This study: from ice-poor streams $(n=7)$ \\
\hline DIC, ice-rich & $-7.0 \pm 0.5$ & $-101.3 \pm 76.1$ & $790 \pm 690$ & This study: from ice-rich streams $(n=5)$ \\
\hline \multicolumn{5}{|c|}{ Model 3: C sources to resident fish } \\
\hline DOC, ice-poor & $-26.5 \pm 1.9$ & $-112.4 \pm 83.4$ & $890 \pm 760$ & This study: from ice-poor streams $(n=7)$ \\
\hline DOC, ice-rich & $-27.8 \pm 0.5$ & $-47.6 \pm 38.5$ & $330 \pm 330$ & This study: from ice-rich streams $(n=5)$ \\
\hline Inverts, ice-poor & $-35.8 \pm 1.1$ & $-330.3 \pm 81.6$ & $3240 \pm 1010$ & $\begin{array}{l}\text { This study: average of all stoneflies and chironomids } \\
\text { from ice-poor streams }(n=13)\end{array}$ \\
\hline Inverts, ice-rich & $-36.2 \pm 2.9$ & $-69.2 \pm 58.1$ & $510 \pm 510$ & $\begin{array}{l}\text { This study: average of all stoneflies and chironomids } \\
\text { from ice-rich streams }(n=10)\end{array}$ \\
\hline
\end{tabular}

watersheds where stream discharge originates from primarily deep groundwater flow paths, SUVA $_{254}$ values tend to be low $\left(<2 \mathrm{~L} \mathrm{mgC}^{-1} \mathrm{~m}^{-1}\right) \cdot \Delta^{14} \mathrm{C}-$ DIC was negatively correlated with specific conductivity values across study streams (Figure 4B), suggesting that DIC is older in streams with increasing groundwater contributions to discharge.

\section{C source Contribution to the Stream DOC Pool}

Stream DOC is derived from a mixture of contemporary and old organic matter, and from allochthonous and autochthonous C sources (Figure 5). The two-isotope mixing model (Model 1) indicates that contemporary terrestrial $\mathrm{C}$ (that is, shallow peat) contributed $22 \pm 16 \%$ to DOC in icepoor sites and $30 \pm 17 \%$ in ice-rich sites (Figure 8; Table 3). Older deep peat (mean ${ }^{14} \mathrm{C}$ age $=530 \pm$ 190 y BP) contributed $48 \pm 22 \%$ and $47 \pm 21 \%$ to stream DOC in ice-poor and ice-rich sites, respectively. Near-surface permafrost $\left({ }^{14} \mathrm{C}\right.$ age $=$ 5490 y BP) was a less important contributor to DOC in headwater streams, averaging $14 \pm 14 \%$ and $11 \pm 11 \%$ in ice-poor and ice-rich sites, respectively. Similarly, the contribution of autochthonous sources (that is, benthic biofilm) to stream DOC was minor and varied between site types, with a greater contribution in ice-poor sites $(16 \pm 13 \%)$ than ice-rich sites $(13 \pm 11 \%)$.

\section{Isotopic Composition of Stream Food Webs}

We observed considerable differences in the C isotope composition of food web components across streams draining ice-rich and ice-poor terrain, including benthic biofilm, benthic macroinvertebrates, and resident fish (Figures 3, 5, 6, 7). Stable $\mathrm{C}$ isotope composition of benthic biofilm was depleted in ice-rich sites $\left(\delta^{13} \mathrm{C}=-37 \pm 5 \%\right)$ compared to ice-poor sites $\left(\delta^{13} \mathrm{C}=-29 \pm 3 \%\right.$; Figure 6, Supplemental Table 1). The $\Delta^{14} \mathrm{C}$ signature of benthic biofilm was lower in ice-poor sites $\left(\Delta^{14} \mathrm{C}=-381 \pm 90 \%\right)$ than in ice-rich sites $\left(\Delta^{14} \mathrm{C}=-118 \pm 83 \% ; \quad d f=1, \quad F=26.2\right.$, $P<0.001) .{ }^{14} \mathrm{C}$ ages of benthic biofilm for ice-poor sites ranged from 1740 to 5255 y BP, whereas radiocarbon ages in ice-rich sites ranged from 215 to 1965 y BP (Figure 6; Supplemental Table 1). This spatial pattern of $\Delta^{14} \mathrm{C}$ of benthic biofilm between sites based on permafrost type appears to reflect pattern of $\Delta{ }^{14} \mathrm{C}$-DIC across streams. Benthic macroinvertebrates (chironomids, stoneflies) and 

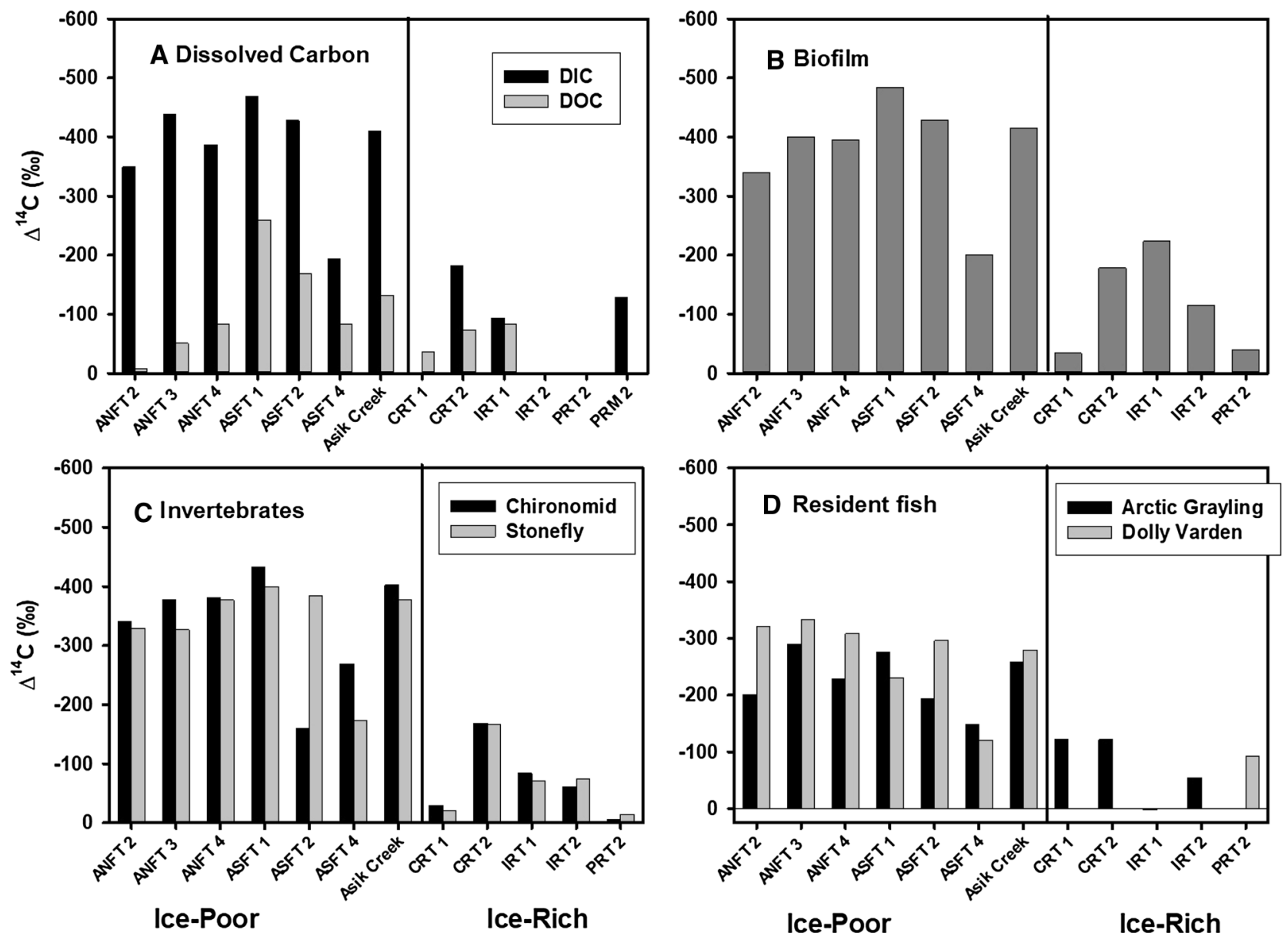

Figure 3. $\Delta^{14} \mathrm{C}$ values for $\mathbf{A}$ dissolved $\mathrm{C}$ species, $\mathbf{B}$ benthic biofilm, $\mathbf{C}$ benthic macroinvertebrates, and $\mathbf{D}$ resident fish species for individual streams draining watersheds underlain by ice-poor (left) and ice-rich (right) permafrost. All ${ }^{14} \mathrm{C}$ data ( $\mathrm{fM},{ }^{14} \mathrm{C}$ age, and analytical uncertainties) are reported in Supplemental Table 1. Site identifiers: ANFT 2, 3 , 4 = Agashashok North Fork Tributaries 2, 3, 4; ASFT 1, 2, 4 = Agashashok South Fork Tributaries 1, 2, 4; CRT 1, 2 = Cutler River Tributaries 1, 2; IRT 1, 2 = Imelyak River Tributaries 1, 2; PRT 2 = Pish River Tributary 2.
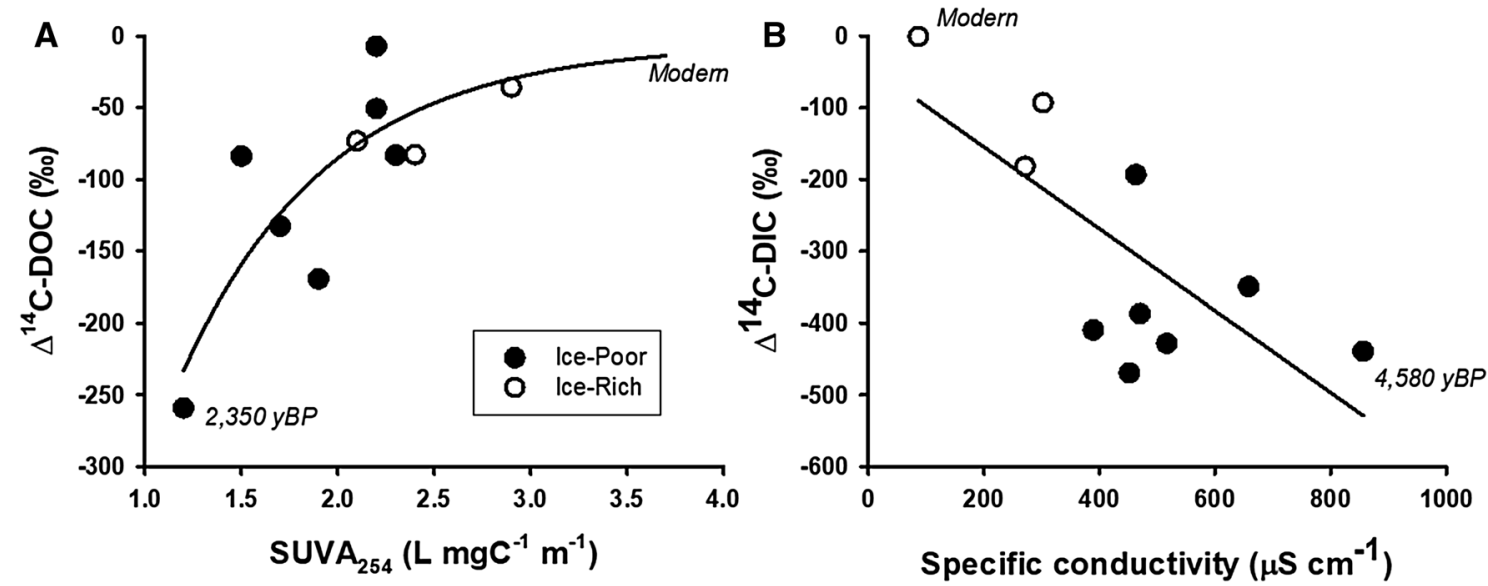

Figure 4. Relationships between $\mathbf{A} \Delta^{14} \mathrm{C}$-DOC and $\mathrm{SUVA}_{254}$ and $\mathbf{B} \Delta^{14} \mathrm{C}$-DIC and specific conductivity. Regression results are characterized by the following equations: $\Delta^{14} \mathrm{C}$-DOC $=-1102+1097 \times\left(1-\mathrm{e}^{-1.31 \times \text { SUVA }} ; R^{2}=0.70, P=0.008\right)$ and $\Delta^{14} \mathrm{C}$-DIC $=-0.57 \times$ Conductivity $-40.41\left(R^{2}=0.54, P=0.02\right)$. 

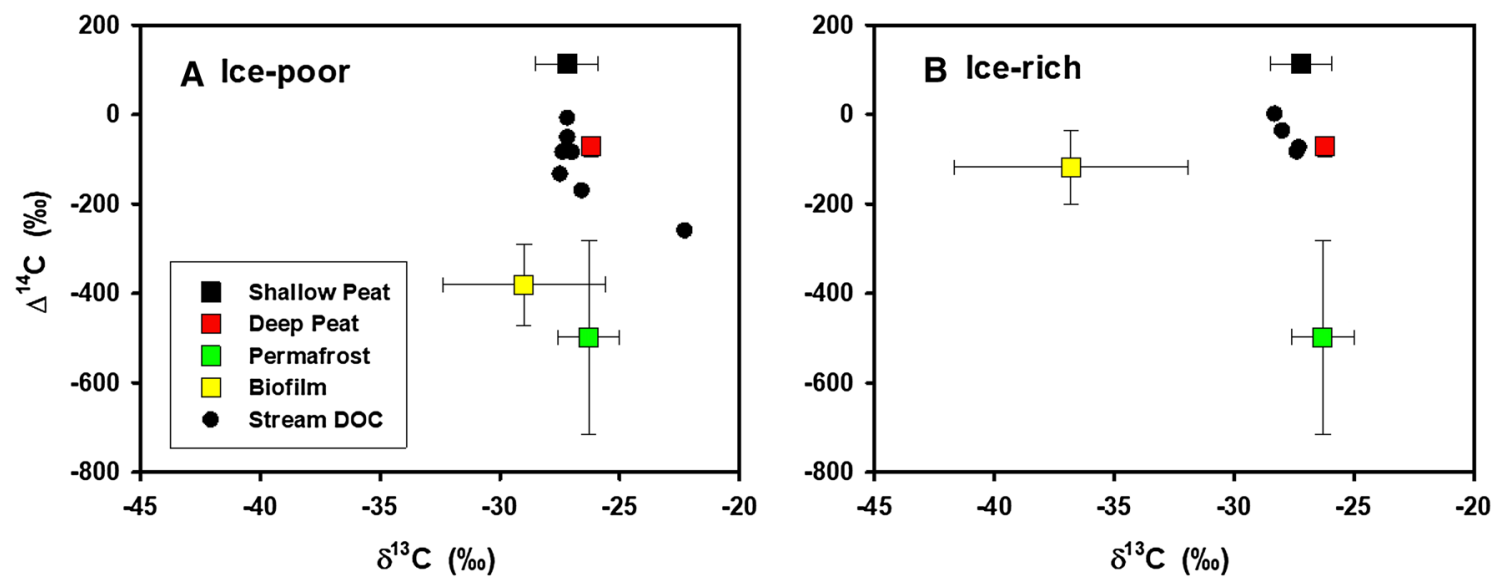

Figure 5. Isotope biplot of $\Delta^{14} \mathrm{C}$ and $\delta^{13} \mathrm{C}$ content of $\mathrm{C}$ sources contributing to stream DoC pool composition across streams draining $\mathbf{A}$ ice-poor and $\mathbf{B}$ ice-rich terrain. Terrestrial C pools include contemporary (shallow peat) and older C sources (deep peat, near-surface permafrost). The $\Delta^{14} \mathrm{C}$ of benthic biofilm was driven primarily by the age of older carbonates in the watershed. Shallow and deep peat samples were collected from the Cutler River basin (Table 2). The near-surface permafrost end-member was defined as frozen $\mathrm{C}$ horizon samples in the top meter of soil from north-facing slopes in interior Alaska. (O’Donnell and others 2011).

Table 3. Summary of Model Output from MixSIAR Isotopic Mixing Analyses from Isotopic Mixing Analyses Across Permafrost Hydrology (that is, Ice-Poor vs. Ice-Rich)

\begin{tabular}{llc}
\hline Sources & \multicolumn{2}{l}{ Mean contribution \pm standard deviation (\%) } \\
\cline { 2 - 3 } & Ice-poor watersheds & Ice-rich watersheds \\
\hline Model 1: Organic C sources to stream DOC? & $22 \pm 16$ & $30 \pm 17$ \\
Shallow peat & $48 \pm 22$ & $47 \pm 21$ \\
Deep peat & $14 \pm 14$ & $11 \pm 11$ \\
Permafrost & $16 \pm 13$ & $13 \pm 11$ \\
Biofilm & $47 \pm 26$ & $42 \pm 26$ \\
Model 2: C sources assimilated by benthic biofilm & $58 \pm 26$ \\
DOC & $53 \pm 26$ & $59 \pm 27$ \\
DIC & $53 \pm 9$ & $41 \pm 27$ \\
Model 3: C sources to Arctic Grayling & $47 \pm 9$ & 75 \\
DOC & & 25 \\
Inverts & $40 \pm 16$ & \\
Model 3: C sources to Dolly Varden & $60 \pm 16$ & \\
DOC & & \\
Inverts & &
\end{tabular}

No standard deviation for ice-rich Dolly Varden, because $n=1$. Model 1 shows the contribution of four end-members to the stream DOC pool. Model 2 shows the contribution of DOC and DIC to benthic biofilm. Model 3 illustrates the contribution of DOC and benthic invertebrates to Arctic Grayling and Dolly Varden.

resident fish species (Arctic Grayling, Dolly Varden) followed a similar pattern in $\Delta^{14} \mathrm{C}$ between ice-rich and ice-poor sites (Figure 3), reflecting $\mathrm{C}$ flow from primary producers up through consumers at higher trophic levels. Interestingly, the isotopic composition of chironomids and stoneflies was nearly identical in most systems (Figure 3, Supplemental Table 1), suggesting that they draw on similar carbon sources for diet in the ice-rich systems. Juvenile Arctic Grayling and Dolly Varden were also similar in stable isotopic composition but different in $\Delta^{14} \mathrm{C}$ between ice-rich and ice-poor terrain (Figure 3, Supplemental Table 1). For instance, Arctic Grayling averaged $-228 \pm 50$ and $-73.7 \pm 59 \%$ in ice-poor and ice-rich terrain, respectively $(d r=1, F=20.9 ; P=0.001)$. 

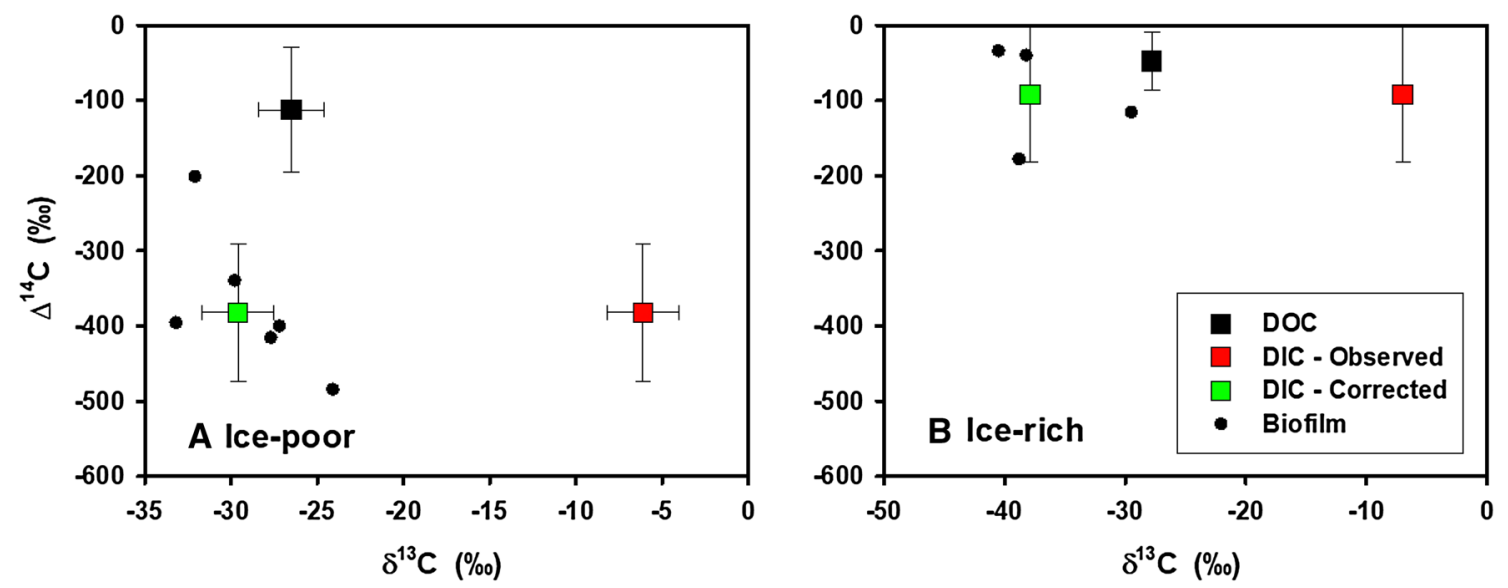

Figure 6. Isotope biplot of $\Delta^{14} \mathrm{C}$ and $\delta^{13} \mathrm{C}$ content of C sources contributing to isotopic composition of benthic biofilm in streams draining $\mathbf{A}$ ice-rich and $\mathbf{B}$ ice-poor terrain. We used two end-members to distinguish possible pathways of $\mathrm{C}$ assimilation, including DOC uptake by aquatic heterotrophs and DIC uptake by benthic algae. We plotted both the observed $\delta^{13} \mathrm{C}$-DIC values and the $\delta^{13} \mathrm{C}$-DIC values corrected for photosynthetic fractionation (following Eq. (1)).
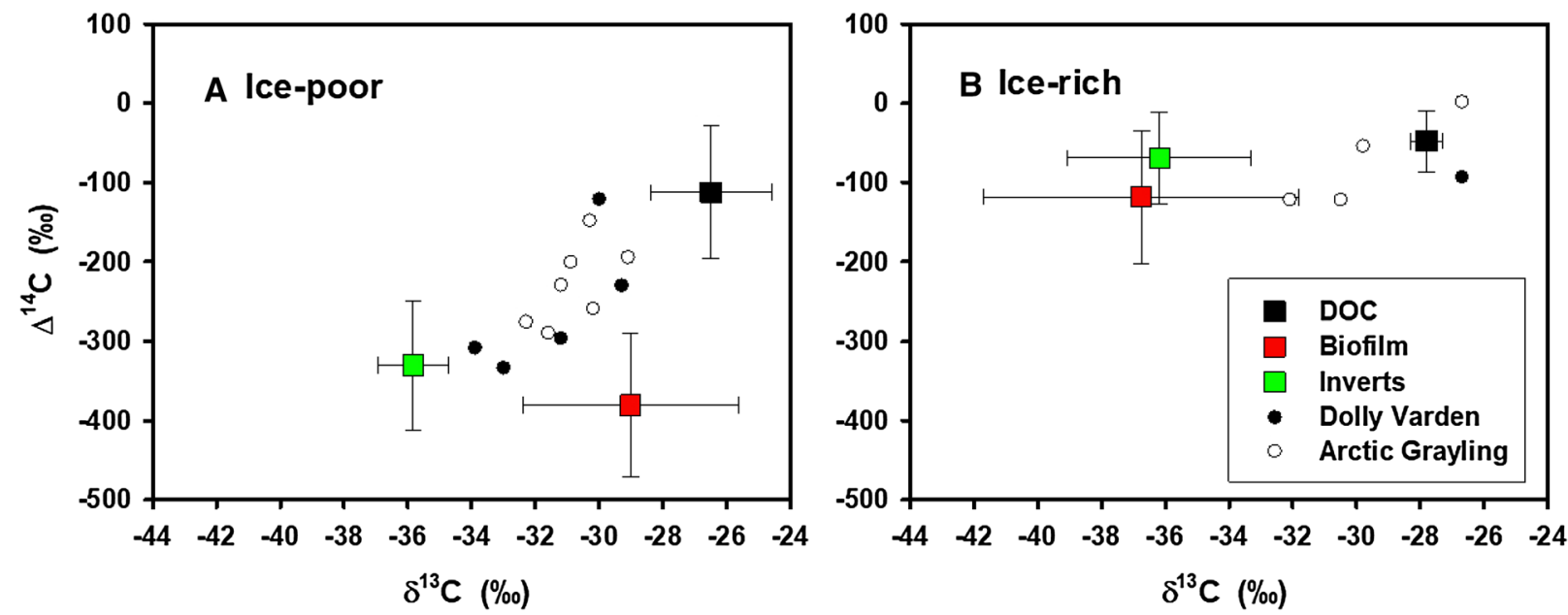

Figure 7. Isotope biplot of $\Delta^{14} \mathrm{C}$ and $\delta^{13} \mathrm{C}$ content of $\mathrm{C}$ sources contributing to resident fish diet across streams draining $\mathbf{A}$ ice-poor and B ice-rich terrain. DOC originates primarily from terrestrial organic matter (Figure 3, Table 3). Benthic biofilm end-member values reflect the mean for both site types. The invertebrate end-member reflects the mean isotopic composition of stoneflies and chironomids for each site type.

\section{Assimilation of C by Stream Food Web}

We conducted a simple mixing analysis to partition C source contribution (DOC vs. DIC) to benthic biofilm in all study streams (Model 2; Figure 6; Table 2). Our findings indicate that both DIC and DOC uptake by benthic biofilm are important pathways of $C$ assimilation in streams draining icepoor terrain (Figure 8; Table 3). DIC uptake by benthic biofilm accounted for $53 \pm 26 \%$ and $58 \pm 26 \%$ of biofilm isotopic composition in icepoor and ice-rich streams, respectively (Table 3). DOC uptake by stream heterotrophs accounts for $47 \pm 26 \%$ and $42 \pm 26 \%$ of biofilm isotopic com- position in ice-poor and ice-rich streams, respectively. Our findings indicate that there are large uncertainties (that is, high standard deviation) associated with both DOC and DIC end-member contribution to biofilm (Table 3).

We conducted a mixing analysis to partition the relative contribution of DOC and benthic macroinvertebrates to resident fish diet (Model 3; Figure 7; Table 2). Although fish cannot directly assimilate DOC, the isotopic composition of fish could not be accounted for without inclusion of an isotopic end-member for DOC (or by proxy, peat; Figure 7). In these streams, particulate organic $C$ (POC) comprises a very low proportion of total 

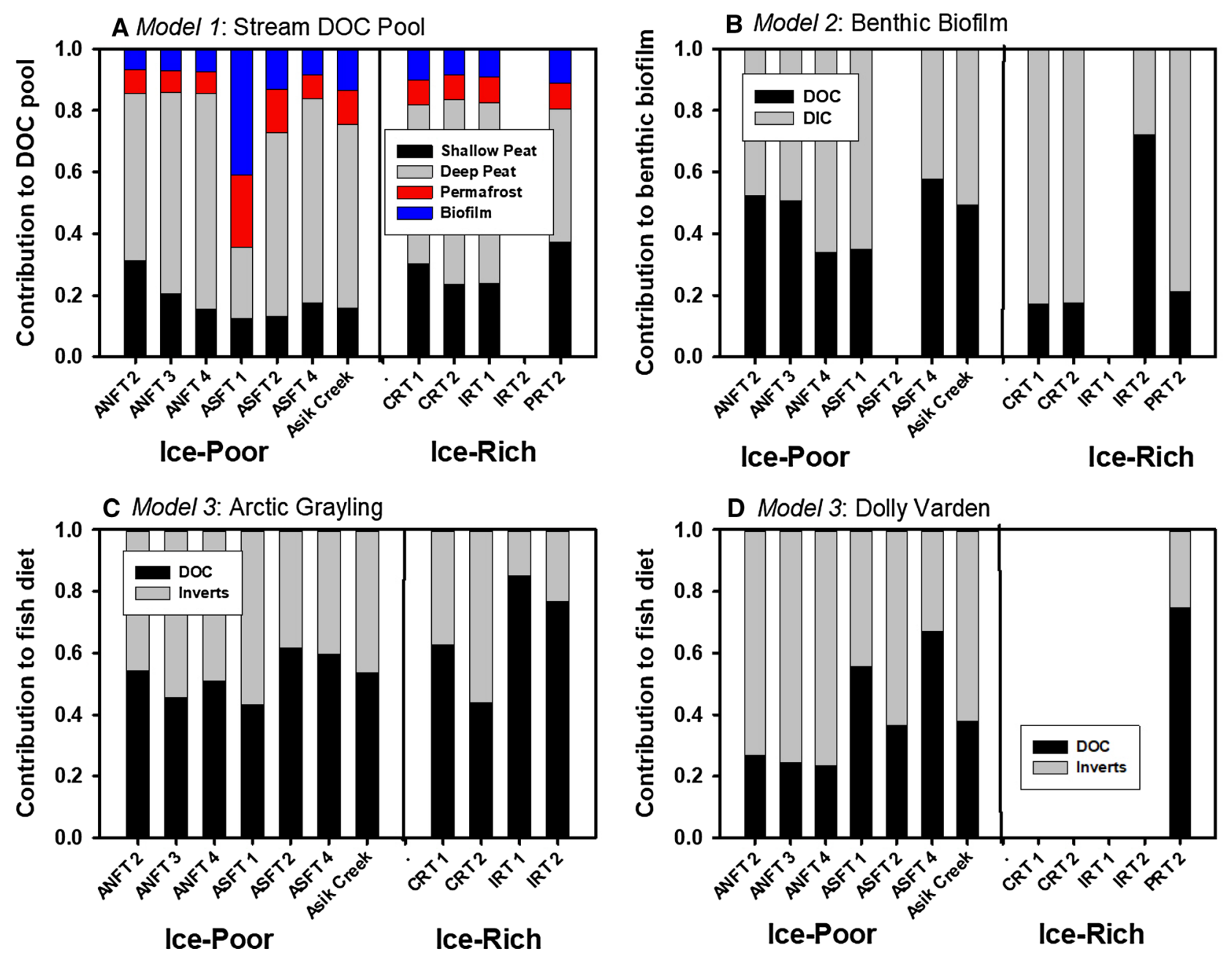

Figure 8. Output from isotopic mixing analyses across permafrost hydrology (that is, ice-poor (left) vs. ice-rich (right)). A Results of Model 1, showing the contribution of four end-members to the stream DOC pool. B Results of Model 2, showing the contribution of DOC and DIC to benthic biofilm. Model 3 illustrates the contribution of DOC and benthic invertebrates to $\mathbf{C}$ Arctic Grayling and D Dolly Varden.

organic C ( $<5 \%$; O'Donnell and others 2015) and therefore is likely not an important contributor to fish diet. It is likely, however, that DOC may be assimilated into fish through macroinvertebrate taxa not sampled in this study. In streams draining ice-poor terrain, mixing model results suggest that the diets of juvenile Arctic Grayling and Dolly Varden are derived from both DOC $(40-53 \%)$ and benthic macroinvertebrates $(47-60 \%)$, the latter determined by the isotopic composition of chironomids and stoneflies (Figure 7; Supplemental Table 1). In streams draining ice-rich terrain, DOC was the primary contributor to juvenile Arctic Grayling diet ( $59 \pm 27 \%)$, with macroinvertebrates $(41 \pm 27 \%)$ comprising a smaller proportion of fish isotopic composition. In ice-rich systems, benthic macroinvertebrates are nearly identical to biofilm
(Figure 7). In ice-poor terrain, macroinvertebrates and biofilm are isotopically different, indicating that their diet may consist of additional sources not sampled in this study. Across stream types, it appears that Arctic Grayling rely more on DOC than stoneflies and chironomids for feeding in comparison with Dolly Varden, with the exception of the C-rich Pish River (Figure 8C, D).

To evaluate the importance of older organic $\mathrm{C}$ to stream food webs, we estimated the contribution of older DOC (pre-1950s) to benthic biofilm composition and resident fish diet. To calculate the fraction of biofilm tissue and fish diet derived from older DOC, we first determined the fraction of stream DOC derived from old terrestrial $\mathrm{C}$ by summing contributions from deep peat $\left({ }^{14} \mathrm{C}\right.$ age $=$ $530 \mathrm{y} \mathrm{BP})$ and near-surface permafrost $\left({ }^{14} \mathrm{C}\right.$ 
age $=5490$ y BP). We then multiplied that amount (fraction of old DOC) by the fraction of biofilm tissue or fish diet comprised of DOC. Benthic biofilm was derived from a moderate amount of old DOC, averaging $30 \pm 9 \%$ and $11 \pm 1 \%$ in ice-poor and ice-rich streams, respectively. By comparison, old DOC was slightly larger contributor to fish diet, averaging $36 \pm 9 \%$ and $41 \pm 14 \%$ for Arctic Grayling in ice-poor and ice-rich streams, respectively. Old C contributed $26 \pm 11 \%$ to Dolly Varden diet in ice-poor streams and 38\% $(n=1$ fish) in ice-rich streams. We conducted regression analyses to evaluate possible linkages between fish size and nutritional status (for example, length at age, energy density) and the fraction of fish diet derived from old DOC. We observed negative relationships (where $P<0.10$ ) between length at age and fish diet derived from old $\mathrm{C}$ for age- 1 Arctic Grayling and age-2 Dolly Varden, but not age-1 Dolly Varden (Figure 9A). We also observed a negative relationship between energy density and fish diet from old $C$ for Arctic Grayling $(P=0.06)$, but no relationship for Dolly Varden (Figure 9B).

\section{Discussion}

\section{Assimilation of Old Dissolved Carbon by Stream Biofilm in the Arctic}

Our findings indicate that old organic and inorganic $\mathrm{C}$ from waters draining permafrost landscapes can be assimilated by biofilm in arctic streams. The radiocarbon age of food web components (benthic biofilm, benthic macroinvertebrates, and juvenile resident fish) ranged from more than 5000 years BP to modern. To correctly interpret the contribution of old organic matter sources to stream biota, it is critical to account for the uptake of DIC by primary producers. This process reflects a "reservoir effect" (Ishikawa and others 2015; Keaveney and others 2015; Guillemette and others 2017), as carbonate dissolution and groundwater transport delivers old DIC from underlying bedrock to streams, depleting the $\Delta^{14} \mathrm{C}$ content of DIC and aquatic biota. The magnitude of the reservoir effect in our study streams indicated by depleted $\Delta^{14} \mathrm{C}$ signatures of DIC in streams varied spatially, mainly due to the differences in permafrost hydrology. In streams draining watersheds underlain by ice-poor carbonate bedrock, DIC was substantially older than in streams draining watersheds underlain by ice-rich, fine-grained deposits. Regression analyses indicate that DIC age is closely linked to relative groundwater influence across our study streams, as inferred by specific conductivity measurements. Our mixing model results further illustrate that uptake of old DIC is an important pathway of $\mathrm{C}$ incorporation into the food web of streams draining ice-poor terrain. This observation helps explain the highly depleted $\Delta^{14} \mathrm{C}$ content of biofilm communities. In addition to DIC uptake by primary producers, we quantified DOC assimilation by aquatic microbes within the biofilm community (Battin and others 2016). Here, we observed similar uptake or assimilation of DOC by the biofilms across streams draining ice-rich and ice-poor terrain, which accounts for $42-47 \%$ of biofilm isotopic composition, on average. These relative contributions of DOC to biofilm are intermediate in value to other observations in glacial streams (49-64\%) and non-glacial streams $(2 \%)$ in southeast Alaska (Fellman and others 2015). Still large uncertainties exist regarding the relative contribution of DOC and DIC to benthic biofilm in our study streams. To reduce these uncertainties, future sampling should aim to better characterize spatial patterns of biofilm across stream reaches (riffle vs. run vs. pool) and biofilm community composition, potentially using molecular techniques (for example, Besemer and others 2012; Ishikawa and others 2015).

\section{Contemporary and Old Sources to Stream DOC Pool}

In the Arctic, the transfer of terrigenous DOC from watershed soils to rivers, estuaries, and the Arctic Ocean represents a critical component of the arctic $\mathrm{C}$ budget that is sensitive to changing climate and disturbance regimes in the region (McGuire and others 2010). Evidence indicates that warming and permafrost thaw will mobilize $\mathrm{C}$ that has been frozen for millennia, releasing ${ }^{14} \mathrm{C}$-depleted $\mathrm{C}$ to the atmosphere (Schuur and others 2015) and surface waters (Spencer and others 2015). In headwater streams of northwest Alaska, our findings indicate that the age of stream DOC ranges from 3430 years BP to modern (post-1950) under summer baseflow conditions. Spatial variation in $\Delta^{14} \mathrm{C}$-DOC signatures appears to vary with subsurface hydrology, as determined by permafrost characteristics such as soil parent material and ground-ice content (O'Donnell and others 2016). Streams draining watersheds underlain by ice-poor bedrock often have older DOC, with ${ }^{14} \mathrm{C}$ ages comparable to those of ground-water dominated streams of the Yukon River basin (Aiken and others 2014). DOC in streams draining ice-rich terrain is comparatively younger, which suggests that large scale of mobilization of permafrost $C$ from ice-rich 

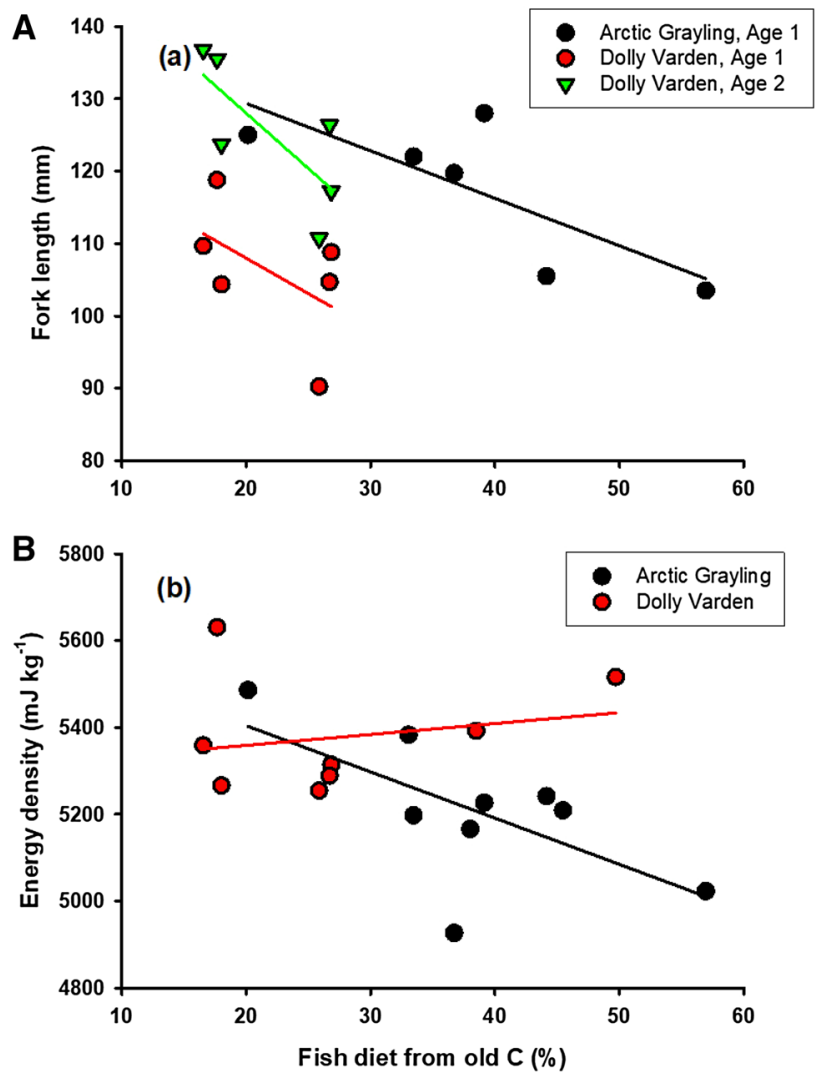

Figure 9. A Relationship between length at age ( $\mathrm{mm})$ and fish diet derived from old DOC (\%) for Arctic Grayling at age 1 (linear regression: $\left.R^{2}=0.59 ; P=0.07\right)$ and Dolly Varden at age $1\left(R^{2}=0.27 ; P=0.28\right)$ and $2\left(R^{2}=0.57 ; P=0.08\right)$. To determine this, we multiplied the fraction of DOC derived from deep peat and near-surface permafrost by the fraction of fish derived from DOC. B Relationship between energy density $\left(\mathrm{mJ} \mathrm{kg}^{-1}\right)$ and fish diet derived from old C for Arctic Grayling $\left(R^{2}=0.41, P=0.06\right)$ and Dolly Varden $(P=0.60)$.

valley-bottom and hillslope soils has not occurred yet.

The relative contribution of contemporary versus old terrestrial DOC to aquatic ecosystems has important implications for aquatic carbon cycling and food web dynamics. The chemical characteristics of contemporary or young DOM are often associated with high bio-lability and nutrient content (Guillemette and others 2017), which can fuel high rates of aquatic production (Berggren and others 2009). By contrast, older DOC (non-permafrost) in surface waters may be more degraded, less bio-labile, and depleted in nutrient content (Kellerman and others 2018). DOC in permafrost, however, can be both old and bio-labile upon thaw due to the low microbial activity in frozen ground (Mikan and others 2002; Drake and others 2015; Ewing and others 2015). Our findings indicate that approximately one-third of the stream DOC pool was derived from shallow peat, a contemporary terrestrial C source (since 1950s), and more than half was derived from older terrestrial sources (deep peat and permafrost; > 5000 y BP). We further observed that younger DOC from ice-rich terrain is more aromatic (as indicated by higher SUVA $_{254}$ values) compared to the older DOC in streams draining ice-poor terrain. These patterns are consistent with prior observations linking DOC age and aromaticity, and the first established agecomposition relationships across different permafrost terrain types (Butman and others 2012; Aiken and others 2014; O'Donnell and others 2014). As permafrost thaws, groundwater contributions to stream flow increase (Walvoord and Striegl 2007; Walvoord and others 2012), and subsequently, $\mathrm{SUVA}_{254}$ values decline, reflecting lower DOM aromaticity (O'Donnell and others 2012). Using fluorescence spectroscopy, O'Donnell and others (2016) documented higher protein-like fluorescence in streams draining ice-poor terrain, 
which may reflect larger contributions from deeper groundwater flow paths or from nitrogen-enriched microbial sources (Cory and others 2007).

Of the older terrestrial organic C sources, deep peat layers of the active layer appear to be the primary contributor to the stream DOC pool. Our findings indicate that near-surface permafrost $\mathrm{C}$ $(\sim 5000$ y BP) was a relatively minor contributor to the stream DOC pool in these headwater reaches, which could be due to the following. First, permafrost in the region is not actively thawing at an appreciable scale to drive old C mobilization and detection in streams. This hypothesis is supported by soil thermal modeling of Panda and others (2016), who showed that near-surface permafrost in the region is largely intact, but will likely experience widespread warming and thawing by 2100 . Second, permafrost DOC is highly bio-labile and susceptible to rapid and preferential mineralization upon thaw in soil pore waters and in small streams (Drake and others 2015; Mann and others 2015; Spencer and others 2015) and thus is often not detected in high-order streams and rivers (Aiken and others 2014). Thus, as active layer thickness increases and near-surface permafrost $\mathrm{C}$ thaws, a considerable fraction of this thawed $\mathrm{C}$ may be mineralized and lost from subsurface waters during transport to the stream.

\section{Old Organic Carbon Assimilation by Fish and Implications for Growth and Nutritional Status}

An increasing number of studies are using natural abundance of ${ }^{14} \mathrm{C}$ to trace old organic matter assimilation into modern food webs, including higher trophic levels such as fish (see Bellamy and Bauer 2017; Guillemette and others 2017, and citations therein). Given the large amount of old C in permafrost soils, it is likely that a fraction of this $\mathrm{C}$ is assimilated by fish upon permafrost thaw, but almost no studies have examined this process to date. One exception is the work of Schell (1983), who documented the assimilation of old $\mathrm{C}$ from Holocene peat deposits by estuarine fish in northern Alaska, likely through their consumption of peat-metabolizing amphipods in the estuary water column. Here, we show that juvenile, resident fish (Arctic Grayling, Dolly Varden) also depend strongly on resources supported by old terrestrial peat, as reflected by the large contributions (53$62 \%$ ) of DOC to fish isotopic composition. Stoneflies and chironomids also reflect a large fraction of fish diet, contributing $38-47 \%$ (collectively) to the isotopic composition of Arctic Grayling and Dolly Varden.

Our findings suggest that DOC is an important component of fish isotopic content and consequently reflects a critical pathway for old organic C in stream ecosystems. While fish cannot directly assimilate DOC, it may serve as a proxy for other pathways of organic $\mathrm{C}$ assimilation. We considered several possibilities to explain the apparent influence of DOC on fish isotopic content. First, it is possible that DOC may actually reflect the isotopic content of POC, which was not measured in this study, but can serve as an important $C$ source to food webs in glacially influenced streams (Fellman and others 2015). However, POC comprises a small fraction of total organic $\mathrm{C}$ in our study streams ( $<5 \%$; O'Donnell, unpublished data) and therefore is likely a minor source of $\mathrm{C}$ to food webs. Second, our findings indicate that DOC may serve as a proxy for terrestrial peat, as evidenced by the large influence of shallow and deep peat horizons on the stream DOC pool. One possible pathway for peat assimilation into fish is through the decomposition and consumption of terrestrial peat $\mathrm{C}$ by stream detritovores (for example, Schell 1983, Caraco and others 2010; Hågvar and Ohlson 2013). Third, DOC could reflect $\mathrm{C}$ assimilation via decomposition of vascular leaf litter by macroinvertebrates in the functional feeding group "shredders" (Merritt and others 2008). However, this pathway of C uptake may be limited, given that leaf litter inputs to tundra streams are relatively low compared to forested ecosystems (Benfield 1997), particularly prior to fall senescence. Lastly, it is also possible that the sampling plan in this study did not capture important $\mathrm{C}$ source(s) to fish diets due to spatial or temporal gaps. For example, DOC uptake by microbial biofilms in pools or other stream habitats was not sampled or greater POC concentrations in streams were missed during high-flow periods. While further work is needed to better track pathways of DOC or peat assimilation by stream food webs, our findings indicate that the inclusion of a DOC end-member is critical for explaining isotopic patterns in resident fish species.

The question remains how the increased mobilization of old organic $C$ from thawing permafrost will impact fish production in stream ecosystems. The food resource age paradigm suggests that older organic matter is less bio-available and nutritious than younger organic matter (Guillemette and others 2017). Observations that support this paradigms are largely limited to effects at the microbial trophic level (Raymond and Bauer 2001; Mayorga and others 2005; Berggren and others 2009). Our 
findings suggest that the assimilation of old organic C through the food web may be associated with reduced growth and energy density of fish, providing some support for the food resource age paradigm at higher trophic levels. For both juvenile Arctic Grayling and Dolly Varden, we observed negative relationships between length at age and the percentage of fish diet derived from old organic C. Interestingly, energy density of Arctic Grayling tissue also declined with use of old organic C, whereas energy density of Dolly Varden tissue was not related to use of old C. This observation suggests that foraging behavior and metabolic demands may vary considerably between these two resident species. Prior work suggests that Arctic Grayling are drift feeders (Hughes 1998), whereas Dolly Varden primarily forage on benthic communities (Nakano and others 2001). The mechanisms linking old C and fish growth and nutritional status are unresolved and likely complex, but reflect bottom-up controls on stream food web dynamics.

As permafrost thaws and ancient, bio-labile forms of DOC (for example, acetate) are mobilized (Ewing and others 2015), we may expect a shift toward use of older organic matter by stream biota. Primary production in our study streams is likely nutrient-limited (Peterson and others 1993), given that dissolved nitrogen and phosphorus concentrations are at or near detection limits (O'Donnell and others 2015). DOC concentrations are also low in many of the ice-poor streams, where DOC is older compared to ice-rich streams. Mineralization of older terrestrial DOM may function to alleviate nutrient limitation in these oligotrophic systems. Thus, it is critical to establish baseline conditions to compare against future increases in delivery and use of old DOC by stream food webs.

\section{Conclusions}

Our findings document the assimilation of old terrestrial C by biota in headwater streams of Arctic Alaska. We further document important spatial patterns in the age and form of dissolved $\mathrm{C}$ in arctic streams, and how these patterns drive isotopic composition of stream biota. These observations indicate that watershed hydrology, as determined by permafrost characteristics (ground-ice content, soil hydraulic properties, depth of flow path), is a primary driver of $\mathrm{C}$ age, form, and assimilation pathway in arctic streams. Model results suggest that much of the old DOC is derived from deep peat, and to a lesser extent, near-surface permafrost. However, as permafrost continues to thaw, we expect the relative contributions from permafrost $\mathrm{C}$ to stream ecosystems to increase. While our findings suggest that increasing contributions of old C may hamper fish growth and nutritional status in headwater streams, more experimental work is needed to better understand the mechanisms underlying these observations. Finally, our findings also highlight the importance of characterizing the isotopic composition of inorganic $C$ in stream food web studies, which can deplete $\Delta^{14} \mathrm{C}$ values of benthic biofilm and other food web components. By accounting for old DIC, we were better able to interpret patterns and drivers of $\mathrm{C}$ isotopes in stream biota and to partition contributions from organic matter released from thawing permafrost.

\section{ACKNOWLEDGEMENTS}

This work was part of the U.S. Geological Survey (USGS) Changing Arctic Ecosystem Initiative and was supported by the Wildlife Program of the USGS Ecosystem Mission Area. Funding was also provided by the Fish Program of the USGS Ecosystem Mission Area and the USGS Water Mission Area. Additional support was provided by the National Park Service's Arctic Inventory and Monitoring Network. The authors thank Mike Records, Ylva Sjoberg, and Dereka Chargualaf for assisting with field work, and Sara Breitmeyer (U.S. Geological Survey) for conducting laboratory analyses of DOM composition. We thank the editor, subject-matter editor, and two anonymous reviewers for their comments and edits, which greatly improved our manuscript. Any use of trade, firm, or product names is for descriptive purposes only and does not imply endorsement by the U.S. Government.

\section{REFERENCES}

Aiken GR. 1992. Chloride interference in the analysis of dissolved organic carbon by the wet oxidation method. Environmental Science and Technology 26:2435-9.

Aiken GR, Spencer RGM, Striegl RG, Schuster PF, Raymond PA. 2014. Influences of glacier melt and permafrost thaw on the age of dissolved organic carbon in the Yukon River basin. Global Biogeochemical Cycles 28:525-37.

Barnes RT, Butman DE, Wilson HF, Raymond PA. 2018. Riverine export of aged carbon drive by flow path depth and residence time. Environmental Science \& Technology 52:102835.

Battin TJ, Besemer K, Bengtsson MM, Romani AM, Packman AI. 2016. The ecology and biogeochemistry of stream biofilms. Nature Reviews 14:251-63.

Beaupre SR, Druffel ERM, Griffin S. 2007. A low-blank photochemical extraction system for concentration and isotopic analyses of marine dissolved organic carbon. Limnology $\delta$ Oceanography Methods 5:174-84. 
Bellamy AR, Bauer JE. 2017. Nutritional support of inland aquatic food webs by aged carbon and organic matter. Limnology and Oceanography Letters 2:131-49.

Benfield EF. 1997. Comparison of litterfall input to streams. Journal of the North American Benthological Society 16:1048.

Berggren M, Laudon H, Jansson M. 2009. Aging of allochthonous organic carbon regulates bacterial production in unproductive boreal lakes. Limnology \& Oceanography 54:1333-42.

Besemer K, Peter H, Logue JB, Langenheder S, Lindstrom ES, Tranvik LJ, Battin TJ. 2012. Unraveling assembly of stream biofilm communities. The ISME Journal 6:1459-68.

Beverly RK, Beaumon W, Tauz D, Ormsby KM, von Reden KF, Santos GM, Southon JR. 2010. The Keck Carbon Cycle AMS Laboratory, University of California, Irvine: status report. Radiocarbon 52:301-9.

Butman D, Raymond PA, Butler K, Aiken G. 2012. Relationships between $14 \mathrm{C}$ and the molecular quality of dissolved organic carbon in rivers draining to the coast from the conterminous United States. Global Biogeochemical Cycles. https://doi.org/ 10.1029/2012GB004361.

Caraco N, Bauer JE, Cole JJ, Petsch S, Raymond P. 2010. Millennial-aged organic carbon subsidies to a modern river food web. Ecology 91:2385-93.

Carey MP, O’Donnell JA, Koch, JC. 2019. Carbon isotope concentrations in stream food webs of the Arctic Network National Parks, Alaska, 2014-2016: U.S. Geological Survey data release, https://doi.org/10.5066/P9NAUIQR.

Cory RM, McKnight DM, Chin YP, Miller P, Jaros CL. 2007. Chemical characteristics of fulvic acids from Arctic surface waters: Microbial contributions and photochemical transformations. Journal of Geophysical Research: Biogeosciences 112. https://doi.org/10.1029/2006JG000343.

Dean JF, Billett MF, Baxter R, Dinsmore KJ, Lessels JS, Street LE, Subke J-A, Tetzlaff D, Washbourne I, Wookey PA. 2016. Biogeochemistry of "pristine" freshwater stream and lake systems in the western Canadian Arctic. Biogeochemistry 130:191-213.

Dean JF, van der Velde Y, Garnett MH, Dinsmore KJ, Baxter R, Lessels JS, Smith P, Street LE, Subke J-A, Tetzlaff D. 2018. Abundant pre-industrial carbon detected in Canadian Arctic headwaters: implications for permafrost carbon feedback. Environmental Research Letters 13:034024. https://doi.org/l 0.1088/1748-9326/aaalfe

Dornblaser MM, Striegl RG. 2015. Switching predominance of organic versus inorganic carbon exports from an intermediate-size subarctic watershed. Geophysical Research Letters 42:386-94.

Drake TW, Wickland KP, Spencer RGM, McKnight DM, Striegl RG. 2015. Ancient low-molecular-weight organic acids in permafrost fuel rapid carbon dioxide production upon thaw. Proceedings of the National Academy of Sciences 112:1394651.

Elder CD, Xu X, Walker J, Schnell JL, Hinkel KM, TownsendSmall A, Arp CD, Pohlman JW, Gaglioti BV, Czimczik CI. 2018. Greenhouse gas emissions from diverse Arctic Alaskan lakes are dominated by young carbon. Nature Climate Change 8:166-71.

Ewing SA, O’Donnell JA, Aiken GR, Butler KD, Butman D, Windham-Myers L, Kanevskiy MZ. 2015. Long-term anoxia and release of ancient, labile carbon upon thaw of Pleistocene permafrost. Geophysical Research Letters 42:10730-38.
Fellman JB, Hood E, Raymond PA, Hudson J, Bozeman M, Arimitsu M. 2015. Evidence for the assimilation of ancient glacier organic carbon in a proglacial stream food web. Limnology and Oceanography 60:1118-28.

Finlay JC. 2004. Patterns and controls of lotic algal stable carbon isotope ratios. Limnology and Oceanography 49:850-61.

Frey KE, McClelland JW. 2009. Impacts of permafrost degradation on arctic river biogeochemistry. Hydrological Processes 23:169-82.

Gao P, Xu X, Zhou L, Pack MA, Griffin S, Santos GM, Southon JR, Liu K. 2014. Rapid sample preparation of dissolved inorganic carbon in natural waters using a headspace-extraction approach for radiocarbon analysis by accelerator mass spectrometry. Limnology and Oceanography: Methods 12:174-90.

Guillemette F, Bianchi TS, Spencer RGM. 2017. Old before your time: ancient carbon incorporation in contemporary aquatic food webs. Limnology and Oceanography 62:1682-700.

Guo L, Ping CL, Macdonald RW. 2007. Mobilization pathways of organic carbon from permafrost to arctic rivers in a changing climate. Geophysical Research Letters 34. https://doi.org/10. 1029/2007Gl030689.

Hågvar S, Ohlson M. 2013. Ancient carbon from a melting glacier gives high $14 \mathrm{C}$ age in living pioneer invertebrates. Scientific Reports 3:2820.

Hood E, Fellman J, Spencer RGM, Hernes PJ, Edwards R, D'Amore D, Scott D. 2009. Glaciers as a source of ancient and labile organic matter to the marine environment. Nature $462(7276): 1044$

Hugelius G, Strauss J, Zubrzycki S, Harden JW, Schuur EAG, Ping CL, Schirrmeister L, Grosse G, Michaelson GJ, Koven CD, O’Donnell JA, Elberling B, Mishra U, Camill P, Yu Z, Palmtag J, Kuhry P. 2014. Estimated stocks of circumpolar permafrost carbon with quantified uncertainty ranges and identified data gaps. Biogeosciences 11:6573-93.

Hughes NF. 1998. A model of habitat selection by drift-feeding stream salmonids at different scales. Ecology 79:281-94.

Ishikawa NF, Uchida M, Shibata Y, Tayasu I. 2014. Carbon storage reservoirs in watersheds support stream food webs via periphyton production. Ecology 95(5):1264-71.

Ishikawa NF, Yamane M, Suga H, Ogawa NO, Yokoyama Y, Ohkouchi N. 2015. Chlorophyll a-specific $\Delta \Delta^{14} \mathrm{C}, \delta^{13} \mathrm{C}$ and $\delta^{15} \mathrm{~N}$ values in stream periphyton: implications for aquatic food web studies. Biogeosciences 12:6781-9.

Kanevskiy M, Shur Y, Fortier D, Jorgenson MT, Stephani E. 2011. Cryostratigraphy of late Pleistocene syngenetic permafrost (yedoma) in northern Alaska, Itkillik River exposure. Quaternary Research 75:584-96.

Keaveney EM, Reimer PJ, Foy RH. 2015. Young, old, and weathered carbon-part 1: using radiocarbon and stable isotopes to identify carbon sources in an alkaline, humic lake. Radiocarbon 57:407-23.

Kellerman AM, Guillemette F, Podgorski DC, Aiken GR, Butler KD, Spencer RG. 2018. Unifying concepts linking dissolved organic matter composition to persistence in aquatic ecosystems. Environmental Science \& Technology 52:2538-48.

Kendall C, Mast M, Rice K. 1992. Tracing watershed weathering reactions with $\delta^{13} \mathrm{C}$. In: Kharaka YK, Maest AS, Eds. Waterrock interaction. Rotterdam: Balkema. p 569-72.

Koch JC, Ewing SA, Striegl R, McKnight DM. 2013. Rapid runoff via shallow throughflow and deeper preferential flow in a boreal catchment underlain by frozen silt (Alaska, USA). Hydrogeology Journal 21:93-106. 
Mann PJ, Eglinton TI, McIntyre CP, Zimov N, Davydova A, Vonk JE, Holmes RM, Spencer RGM. 2015. Utilization of ancient permafrost carbon in headwaters of Arctic fluvial networks. Nature Communications 6:7856.

Mayorga E, Aufdenkampe AK, Masiello CA, Krusche AV, Hedges JI, Quay PD, Richey JE, Brown TA. 2005. Young organic matter as a source of carbon dioxide outgassing from Amazonian rivers. Nature 436:538-41.

McGuire AD, Hayes DJ, Kicklighter DW, Manizza M, Zhuang Q, Chen M, Follows MJ, Gurney KR, McClelland JW, Melillo JM, Peterson BJ. 2010. An analysis of the carbon balance of the Arctic Basin from 1997 to 2006. Tellus B 62:455-74.

Merritt RW, Cummins KW, Berg MB, Eds. 2008. An introduction to the aquatic insects of North America. 4th edn. Dubuque, Iowa: Kendall Hunt Publishing.

Mikan CJ, Schimel JP, Doyle AP. 2002. Temperature controls of microbial respiration in arctic tundra soils above and below freezing. Soil biology and biochemistry 34:1785-95.

Moore JW, Semmens BX. 2008. Incorporating uncertainty and prior information into stable isotope mixing models. Ecology Letters 11:470-80.

Nakano S, Fausch KD, Kitano S. 2001. Flexible niche partitioning via a foraging mode shift: a proposed mechanism for coexistence in stream-dwelling charrs. Journal of Animal Ecology 68:1079-92.

O'Donnell JA, Harden JW, McGuire AD, Kanevskiy MZ, Jorgenson MT, Xu X. 2011. The effect of fire and permafrost interactions on soil carbon accumulation in an upland black spruce ecosystem of interior Alaska: implications for postthaw carbon loss. Global Change Biology 17:1461-74.

O'Donnell JA, Aiken GR, Walvoord MA, Butler KD. 2012. Dissolved organic matter composition of winter flow in the Yukon River basin: Implications of permafrost thaw and increased groundwater discharge. Global Biogeochemical Cycles 26. https://doi.org/10.1029/2012GB004341.

O'Donnell JA, Aiken GR, Walvoord MA, Raymond PA, Butler KD, Dornblaser MM, Heckman K. 2014. Using dissolved organic matter age and composition to detect permafrost thaw in boreal watersheds of interior Alaska. Journal of Geophysical Research: Biogeosciences 119:2155-70.

O'Donnell JA, Aiken GR, Trainor TP, Douglas TA, Butler KD. 2015. Chemical composition of rivers in Alaska's Arctic Network, 2013-2014. Natural Resource Data Series, NPS/ARCN/ NRDS, 809.

O'Donnell JA, Aiken GR, Swanson DK, Panda S, Butler KD, Baltensperger AP. 2016. Dissolved organic matter composition of Arctic rivers: linking permafrost and parent material to riverine carbon. Global Biogeochemical Cycles 30:1811-26.

O'Donnell JA, Harden JW, Manies KL, Jorgenson MT, Kanevskiy MZ. 2013. Soil data from fire and permafrost-thaw chronosequences in upland Picea mariana stands near Hess Creek and Tok, Alaska. US Geological Survey Open-File Report 2013-1045, p 22

Panda SK, Marchenko SS, Romanovsky VE. 2016. High-resolution permafrost modeling in the Arctic Network of National Parks, Preserves and Monuments. Natural Resource Report NPS/ARCN/NRR, 1366.

Peterson BJ, Fry B. 1987. Stable isotopes in ecosystem studies. Annual Review of Ecology and Systematics 18:293-320.

Peterson BJ, Deegan L, Helfrich J, Hobbie JE, Hullar M, Moller B, Ford TE, Hershey A, Hiltner A, Kipphut G, Lock MA, Fiebig DM, McKinley V, Miller MC, Vestal JR, Ventullo R, Volk G.
1993. Biological responses of a tundra river to fertilization. Ecology 74:653-72.

Phillips DL, Koch PL. 2002. Incorporating concentration dependence in stable isotope mixing models. Oecologia 130:114-25.

Raymond PA, Bauer JE. 2001. Use of $14 \mathrm{C}$ and $13 \mathrm{C}$ natural abundances for evaluating riverine, estuarine, and coastal DOC and POC sources and cycling: a review and synthesis. Organic Geochemistry 32:469-85.

Reynolds JB, Kolz AL. 2013. Electrofishing. In: Zale AV, Parrish DL, Sutton TM, Eds. Fisheries techniques. 3rd edn. Bethesda, Maryland: American Fisheries Society. p 305-61.

Schell DM. 1983. Carbon-13 and carbon-14 abundances in Alaskan aquatic organisms: delayed production from peat in arctic food webs. Science 219:1068-71.

Schuur EA, McGuire AD, Schädel C, Grosse G, Harden JW, Hayes DJ, Hugelius G, Koven CD, Kuhry P, Lawrence DM, Natali SM. 2015. Climate change and the permafrost carbon feedback. Nature 520(7546):171.

Small GE, Bixby RJ, Kazanci C, Pringle CM. 2011. Partitioning stoichiometric components of epilithic biofilm using mixing models. Limnology and Oceanography: Methods 9:185-93.

Soil Classification Working Group. 1998. The Canadian system of soil classification. Agriculture and agri-food Canada publication 1646:1-187.

Spencer RGM, Mann PJ, Dittmar T, Eglinton TI, McIntyre C, Holmes RGM, Zimov N, Stubbins A. 2015. Detecting the signature of permafrost thaw in Arctic rivers. Geophysical Research Letters 42:2830-5.

Staff SS. 1998. Keys to Soil Taxonomy. Blacksburg, Virginia: Pocahontas Press Inc.

Stock BC, Semmens BX. 2013. MixSIAR GUI user manual, version 1.0. http://conserver.iugo-cafe.org/user/brice.semme ns/MixSIAR.

Striegl RG, Aiken GR, Dornblaser MM, Raymond PA, Wickland KP. 2005. A decrease in discharge-normalized DOC export by the Yukon River during summer through autumn. Geophysical Research Letters 32(21). https://doi.org/10.1029/2005G L024413.

Stuiver M, Polach HA. 1977. Discussion reporting of 14C data. Radiocarbon 19(3):355-63.

Swanson DK. 2015. Environmental limits of tall shrubs in Alaska's Arctic National Parks. PloS one 10(9):e0138387. h ttps://doi.org/10.1371/journal.pone.0138387.

Tank SE, Striegl RG, McClelland JW, Kokelj SV. 2016. Multidecadal increases in dissolved organic carbon and alkalinity flux from the Mackenzie drainage basin to the Arctic Ocean. Environmental Research Letters 11(5):054015. https://doi.or g/10.1088/1748-9326/11/5/054015.

Tape K, Sturm M, Racine C. 2006. The evidence for shrub expansion in Northern Alaska and the Pan-Arctic. Global Change Biology 12:686-702.

Team RC. 2014. R: A language and environment for statistical computing. https://www.R-project.org/.

Toohey RC, Herman-Mercer NM, Schuster PF, Mutter EA, Koch JC. 2016. Multidecadal increases in the Yukon River Basin of chemical fluxes as indicators of changing flowpaths, groundwater, and permafrost. Geophysical Research Letters 43:12120-30.

Torres ME, Mix AC, Rugh WD. 2005. Precise $\delta 13 C$ analysis of dissolved inorganic carbon in natural waters using automated 
headspace sampling and continuous-flow mass spectrometry. Limnology and Oceanography: Methods 3:349-60.

Walvoord MA, Striegl RG. 2007. Increased groundwater to stream discharge from permafrost thawing in the Yukon River basin: Potential impacts on lateral export of carbon and nitrogen. Geophysical Research Letters 34(12). https://doi.or g/10.1029/2007GL030216.

Walvoord MA, Voss CI, Wellman TP. 2012. Influence of permafrost distribution on groundwater flow in the context of climate-driven permafrost thaw: example from Yukon Flats Basin, Alaska. United States. Water Resources Research. http s://doi.org/10.1029/2011WR011595.

Wauthy M, Rautio M, Christoffersen KS, Forsström L, Laurion I, Mariash HL, Peura S, Vincent WF. 2018. Increasing domi- nance of terrigenous organic matter in circumpolar freshwaters due to permafrost thaw. Limnology and Oceanography Letters 3:186-98.

Weishaar JL, Aiken GR, Bergamaschi BA, Fram MS, Fujii R, Mopper K. 2003. Evaluation of specific ultraviolet absorbance as an indicator of the chemical composition and reactivity of dissolved organic carbon. Environmental science $\&$ technology 37:4702-8.

Xu X, Trumbore SE, Zheng S, Southon JR, McDuffee KE, Luttgen M, Liu JC. 2007. Modifying a sealed tube zinc reduction method for preparation of AMS graphite targets: reducing background and attaining high precision. Nuclear Instruments and Methods in Physics Research Section B: Beam Interactions with Materials and Atoms 259:320-9. 


\section{Supplemental Material}

Supplemental Table 1. Summary of stable carbon and radiocarbon isotope data for carbon sources and stream biota.

\begin{tabular}{|c|c|c|c|c|c|c|c|}
\hline Site ID & Sample Type & $\begin{array}{c}\text { Lab } \\
\text { AMS \# }\end{array}$ & $\begin{array}{c}\text { Sampling } \\
\text { Date }\end{array}$ & $\delta^{13} \mathrm{C}(\%)$ & fM & $\Delta^{14} \mathrm{C}(\%)$ & ${ }^{14} \mathrm{C}$ age (BP) \\
\hline \multicolumn{8}{|c|}{ Ice-Poor Streams } \\
\hline ANFT 2 & DIC & 178690 & $8 / 11 / 2016$ & $-6.6 \pm 0.2$ & $0.6560 \pm 0.0016$ & $-349.3 \pm 1.6$ & $3385 \pm 20$ \\
\hline ANFT 3 & DIC & 178696 & $8 / 11 / 2016$ & $-6.1 \pm 0.2$ & $0.5653 \pm 0.0014$ & $-439.2 \pm 1.4$ & $4580 \pm 20$ \\
\hline ANFT 4 & DIC & 178694 & $8 / 12 / 2016$ & $-7.1 \pm 0.2$ & $0.6179 \pm 0.0015$ & $-387.0 \pm 1.5$ & $3865 \pm 20$ \\
\hline ASFT 1 & DIC & 178695 & $8 / 10 / 2016$ & $-3.3 \pm 0.2$ & $0.5347 \pm 0.0013$ & $-469.5 \pm 1.3$ & $5030 \pm 25$ \\
\hline ASFT 2 & DIC & 178697 & $8 / 10 / 2016$ & $-3.2 \pm 0.2$ & $0.5763 \pm 0.0014$ & $-428.2 \pm 1.4$ & $4425 \pm 20$ \\
\hline ASFT 4 & DIC & 178691 & $8 / 9 / 2016$ & $-8.7 \pm 0.2$ & $0.8132 \pm 0.0019$ & $-193.3 \pm 1.9$ & $1660 \pm 20$ \\
\hline Asik Creek & DIC & 178688 & $8 / 12 / 2016$ & $-7.6 \pm 0.2$ & $0.5951 \pm 0.0014$ & $-409.6 \pm 1.4$ & $4170 \pm 20$ \\
\hline Mean & DIC & & & $-6.1 \pm 2.1$ & $0.6227 \pm .0925$ & $-382.3 \pm 91.8$ & $3810 \pm 1200$ \\
\hline \multicolumn{8}{|c|}{ Ice-Rich Streams } \\
\hline CRT 2 & DIC & 178689 & $8 / 15 / 2016$ & $-6.6 \pm 0.2$ & $0.8249 \pm 0.0019$ & $-181.9 \pm 1.9$ & $1550 \pm 20$ \\
\hline IRT 1 & DIC & 178692 & $8 / 14 / 2016$ & $-7.3 \pm 0.2$ & $0.9141 \pm 0.0021$ & $-93.2 \pm 2.1$ & $720 \pm 20$ \\
\hline PRM 2 & DIC & 184766 & $9 / 11 / 2016$ & - & $0.8780 \pm 0.0015$ & $-129.1 \pm 1.5$ & $1045 \pm 15$ \\
\hline PRT 2 & DIC & 184765 & $9 / 11 / 2016$ & - & $1.0071 \pm 0.0018$ & $-1.0 \pm 1.8$ & Modern \\
\hline Mean & DIC & & & $-7.0 \pm 0.5$ & $0.9060 \pm .0767$ & $-101.3 \pm 76.1$ & $790 \pm 690$ \\
\hline \multicolumn{8}{|c|}{ Ice-Poor Streams } \\
\hline ANFT 2 & DOC & 146792 & $8 / 11 / 2016$ & $-27.2 \pm 0.2$ & $1.0007 \pm 0.015$ & $-7.3 \pm 14.7$ & Modern \\
\hline ANFT 3 & DOC & 146794 & $8 / 11 / 2016$ & $-27.2 \pm 0.2$ & $0.9569 \pm 0.013$ & $-50.7 \pm 13.4$ & $355 \pm 110$ \\
\hline ANFT 4 & DOC & 146790 & $8 / 12 / 2016$ & $-27.0 \pm 0.4$ & $0.9234 \pm 0.032$ & $-83.9 \pm 31.7$ & $640 \pm 280$ \\
\hline ASFT 1 & DOC & 146793 & $8 / 10 / 2016$ & $-22.3 \pm 1.0$ & $0.7467 \pm 0.060$ & $-259.2 \pm 60.2$ & $2350 \pm 650$ \\
\hline ASFT 2 & DOC & 146787 & $8 / 10 / 2016$ & $-26.6 \pm 0.6$ & $0.8372 \pm 0.040$ & $-169.5 \pm 40.4$ & $1430 \pm 390$ \\
\hline ASFT 4 & DOC & 146789 & $8 / 9 / 2016$ & $-27.4 \pm 0.2$ & $0.9241 \pm 0.009$ & $-83.2 \pm 8.9$ & $635 \pm 80$ \\
\hline Asik Creek & DOC & 146788 & $8 / 12 / 2016$ & $-27.5 \pm 0.5$ & $0.8743 \pm 0.033$ & $-132.7 \pm 32.9$ & $1080 \pm 300$ \\
\hline
\end{tabular}




\begin{tabular}{|c|c|c|c|c|c|c|c|}
\hline Mean & DOC & & & $-26.5 \pm 1.9$ & $0.8948 \pm 0.0841$ & $-112.4 \pm 83.4$ & $890 \pm 760$ \\
\hline \multicolumn{8}{|c|}{ Ice-Rich Streams } \\
\hline CRT 1 & DOC & 146796 & $8 / 15 / 2016$ & $-28.0 \pm 0.1$ & $0.9718 \pm 0.005$ & $-35.9 \pm 4.5$ & $230 \pm 35$ \\
\hline CRT 2 & DOC & 146791 & $8 / 15 / 2016$ & $-27.3 \pm 0.1$ & $0.9342 \pm 0.008$ & $-73.2 \pm 7.5$ & $545 \pm 65$ \\
\hline IRT 1 & DOC & 146795 & $8 / 14 / 2016$ & $-27.4 \pm 0.1$ & $0.9245 \pm 0.008$ & $-82.9 \pm 8.2$ & $630 \pm 70$ \\
\hline PRT 2 & DOC & 146797 & $9 / 11 / 2016$ & $-28.3 \pm 0.1$ & $1.0095 \pm 0.004$ & $1.5 \pm 3.9$ & Modern \\
\hline Mean & DOC & & & $-27.8 \pm 0.5$ & $0.9600 \pm 0.039$ & $-47.6 \pm 38.5$ & $330 \pm 330$ \\
\hline Cutler & Moss $(0-4 \mathrm{~cm})$ & 194267 & $7 / 24 / 2014$ & $-28.1 \pm 0.2$ & $1.1342 \pm 0.0024$ & $125.0 \pm 2.4$ & Modern \\
\hline Cutler & Mesic OM $(4-7 \mathrm{~cm})$ & 194264 & $7 / 24 / 2014$ & $-26.3 \pm 0.2$ & $1.1102 \pm 0.0019$ & $101.3 \pm 1.9$ & Modern \\
\hline Cutler & Humic OM (10-15 cm) & 194268 & $7 / 24 / 2014$ & $-26.4 \pm 0.2$ & $0.9592 \pm 0.0018$ & $-48.5 \pm 1.8$ & $335 \pm 20$ \\
\hline Cutler & Humic OM (15-19 cm) & 194265 & $7 / 24 / 2014$ & $-26.2 \pm 0.2$ & $0.9332 \pm 0.0015$ & $-74.3 \pm 1.5$ & $555 \pm 15$ \\
\hline Cutler & Humic OM (19-25 cm) & 194266 & $7 / 24 / 2014$ & $-25.9 \pm 0.2$ & $0.9152 \pm 0.0015$ & $-92.1 \pm 1.5$ & $710 \pm 15$ \\
\hline Cutler & Mean Shallow Peat & & & $-27.2 \pm 1.3$ & $1.1222 \pm 0.0170$ & $113.2 \pm 16.8$ & - \\
\hline Cutler & Mean Deep Peat & & & $-26.2 \pm 0.3$ & $0.9359 \pm 0.0221$ & $-71.6 \pm 21.9$ & $530 \pm 190$ \\
\hline \multicolumn{8}{|c|}{ Ice-Poor Streams } \\
\hline ANFT 2 & Biofilm & 184306 & $8 / 11 / 2016$ & -29.8 & $0.6661 \pm 0.0012$ & $-339.3 \pm 1.2$ & $3265 \pm 15$ \\
\hline ANFT 3 & Biofilm & 184305 & $8 / 11 / 2016$ & -27.2 & $0.6049 \pm 0.0011$ & $-400.0 \pm 1.1$ & $4040 \pm 15$ \\
\hline ANFT 4 & Biofilm & 184304 & $8 / 12 / 2016$ & -33.2 & $0.6093 \pm 0.0011$ & $-395.6 \pm 1.1$ & $3980 \pm 15$ \\
\hline ASFT 1 & Biofilm & 184309 & $8 / 10 / 2016$ & -24.1 & $0.5198 \pm 0.0010$ & $-484.4 \pm 1.0$ & $5255 \pm 15$ \\
\hline ASFT 2 & Biofilm & 184308 & $8 / 10 / 2016$ & - & $0.5766 \pm 0.0013$ & $-428.0 \pm 1.3$ & $4425 \pm 20$ \\
\hline ASFT 4 & Biofilm & 184307 & $8 / 9 / 2016$ & -32.1 & $0.8053 \pm 0.0014$ & $-201.2 \pm 1.4$ & $1740 \pm 15$ \\
\hline Asik Creek & Biofilm & 184303 & $8 / 12 / 2016$ & -27.7 & $0.5892 \pm 0.0011$ & $-415.5 \pm 1.1$ & $4250 \pm 15$ \\
\hline Mean & Biofilm & & & $-29.0 \pm 3.4$ & $0.6245 \pm 0.0909$ & $-380.6 \pm 90.1$ & $3780 \pm 1170$ \\
\hline \multicolumn{8}{|c|}{ Ice-Rich Streams } \\
\hline CRT 1 & Biofilm & 184297 & $8 / 15 / 2016$ & -40.5 & $0.9739 \pm 0.0019$ & $-34.0 \pm 1.9$ & $215 \pm 20$ \\
\hline CRT 2 & Biofilm & 184298 & $8 / 15 / 2016$ & -38.8 & $0.8287 \pm 0.0015$ & $-178.0 \pm 1.5$ & $1510 \pm 15$ \\
\hline IRT 1 & Biofilm & 184299 & $8 / 14 / 2016$ & - & $0.7830 \pm 0.0014$ & $-223.4 \pm 1.4$ & $1965 \pm 15$ \\
\hline IRT 2 & Biofilm & 184300 & $8 / 14 / 2016$ & -29.5 & $0.8917 \pm 0.0015$ & $-115.5 \pm 1.5$ & $920 \pm 15$ \\
\hline PRT 2 & Biofilm & 184301 & $9 / 11 / 2016$ & -38.2 & $0.9678 \pm 0.0016$ & $-40.0 \pm 1.6$ & $265 \pm 15$ \\
\hline
\end{tabular}




\begin{tabular}{|c|c|c|c|c|c|c|c|}
\hline Mean & Biofilm & & & $-36.8 \pm 4.9$ & $0.8890 \pm 0.0841$ & $-118.2 \pm 83.4$ & $950 \pm 760$ \\
\hline \multicolumn{8}{|c|}{ Ice-Poor Streams } \\
\hline ANFT 2 & Stonefly & 194252 & $8 / 11 / 2016$ & $-34.7 \pm 0.2$ & $0.6764 \pm 0.0012$ & $-329.1 \pm 1.2$ & $3140 \pm 15$ \\
\hline ANFT 3 & Stonefly & 194253 & $8 / 11 / 2016$ & $-35.1 \pm 0.2$ & $0.6791 \pm 0.0012$ & $-326.3 \pm 1.2$ & $3110 \pm 15$ \\
\hline ANFT 4 & Stonefly & 194254 & $8 / 12 / 2016$ & - & $0.6282 \pm 0.0011$ & $-376.9 \pm 1.1$ & $3735 \pm 15$ \\
\hline ASFT 1 & Stonefly & 194255 & $8 / 10 / 2016$ & - & $0.6052 \pm 0.0011$ & $-399.7 \pm 1.1$ & $4035 \pm 15$ \\
\hline ASFT 2 & Stonefly & 194256 & $8 / 10 / 2016$ & - & $0.6214 \pm 0.0011$ & $-383.6 \pm 1.1$ & $3820 \pm 15$ \\
\hline ASFT 4 & Stonefly & 194257 & $8 / 9 / 2016$ & - & $0.8344 \pm 0.0062$ & $-172.4 \pm 6.2$ & $1450 \pm 60$ \\
\hline Asik Creek & Stonefly & 194258 & $8 / 12 / 2016$ & - & $0.6271 \pm 0.0043$ & $-378.0 \pm 4.3$ & $3750 \pm 60$ \\
\hline Mean & Stonefly & & & $34.9 \pm 0.3$ & $0.6674 \pm 0.0788$ & $-388.0 \pm 78.1$ & $3520 \pm 950$ \\
\hline \multicolumn{8}{|c|}{ Ice-Rich Streams } \\
\hline CRT 1 & Stonefly & 194261 & $8 / 15 / 2016$ & $-36.4 \pm 0.2$ & $0.9874 \pm 0.0016$ & $-20.5 \pm 1.6$ & $100 \pm 15$ \\
\hline CRT 2 & Stonefly & 194259 & $8 / 15 / 2016$ & - & $0.8409 \pm 0.0015$ & $-165.9 \pm 1.5$ & $1390 \pm 15$ \\
\hline IRT 1 & Stonefly & 194263 & $8 / 14 / 2016$ & $-35.6 \pm 0.2$ & $0.9376 \pm 0.0015$ & $-69.9 \pm 1.5$ & $515 \pm 15$ \\
\hline IRT 2 & Stonefly & 194262 & $8 / 14 / 2016$ & - & $0.9329 \pm 0.0022$ & $-74.6 \pm 2.2$ & $560 \pm 20$ \\
\hline PRT 2 & Stonefly & 184829 & $9 / 11 / 2016$ & - & $0.9940 \pm 0.0018$ & $-14.1 \pm 1.8$ & $50 \pm 15$ \\
\hline Mean & Stonefly & & & $-36.0 \pm 0.6$ & $0.9386 \pm 0.0613$ & $69.0 \pm 60.8$ & $510 \pm 530$ \\
\hline \multicolumn{8}{|c|}{ Ice-Poor Streams } \\
\hline ANFT 2 & Chironomid & 195405 & $8 / 11 / 2016$ & $-37.4 \pm 0.1$ & $0.6658 \pm 0.0011$ & $-339.6 \pm 1.1$ & $3270 \pm 15$ \\
\hline ANFT 3 & Chironomid & 195406 & $8 / 11 / 2016$ & - & $0.6273 \pm 0.0040$ & $-377.8 \pm 4.0$ & $3750 \pm 60$ \\
\hline ANFT 4 & Chironomid & 195407 & $8 / 12 / 2016$ & $-35.4 \pm 0.1$ & $0.6248 \pm 0.0010$ & $-380.2 \pm 1.0$ & $3780 \pm 15$ \\
\hline ASFT 1 & Chironomid & 206514 & $8 / 10 / 2016$ & - & $0.5720 \pm 0.0078$ & $-432.7 \pm 7.8$ & $4490 \pm 110$ \\
\hline ASFT 2 & Chironomid & 195408 & $8 / 10 / 2016$ & - & $0.8472 \pm 0.0037$ & $-159.6 \pm 3.7$ & $1330 \pm 35$ \\
\hline ASFT 4 & Chironomid & 195410 & $8 / 9 / 2016$ & - & $0.7369 \pm 0.0013$ & $-269.1 \pm 1.3$ & $2455 \pm 15$ \\
\hline Asik Creek & Chironomid & 195411 & $8 / 12 / 2016$ & $-36.5 \pm 0.1$ & $0.6031 \pm 0.0011$ & $-401.8 \pm 1.1$ & $4065 \pm 15$ \\
\hline Mean & Chironomid & & & $-27.2 \pm 18.5$ & $0.6682 \pm 0.0947$ & $-321.4 \pm 92.0$ & $3240 \pm 1260$ \\
\hline \multicolumn{8}{|c|}{ Ice-Rich Streams } \\
\hline CRT 1 & Chironomid & 195413 & $8 / 15 / 2016$ & $-32.9 \pm 0.1$ & $0.9790 \pm 0.0017$ & $-28.9 \pm 1.7$ & $170 \pm 15$ \\
\hline CRT 2 & Chironomid & 195412 & $8 / 15 / 2016$ & $-39.8 \pm 0.1$ & $0.8390 \pm 0.0016$ & $-167.8 \pm 1.6$ & $1410 \pm 20$ \\
\hline
\end{tabular}




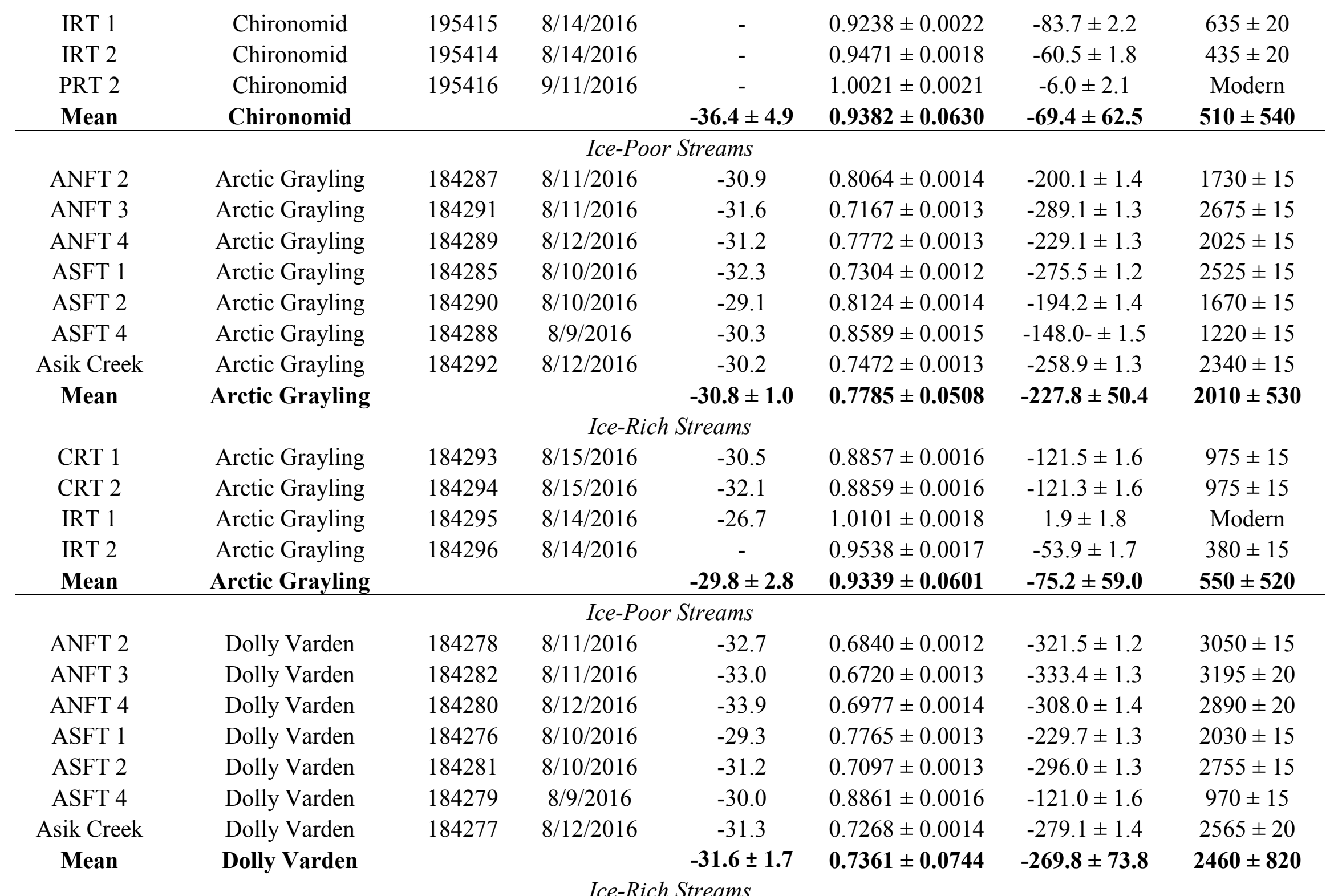


PRT 2

$9 / 11 / 2016$

$-26.7$

$0.9145 \pm 0.0016$

$-92.9 \pm 1.6$

$720 \pm 15$

Note: $\mathrm{fM}=$ fraction modern; $\mathrm{BP}=$ before present which1950; Modern = samples contain excess ${ }^{14} \mathrm{C}$, probably from mid-20th century atmospheric thermonuclear weapons tests.

Error bars represent analytical error, or standard deviation of the measurement. All AMS measurements and lab numbers are associated with the UC Irvine Keck AMS laboratory, except for DOC, which was measured at NOSAMS. 